University of Nebraska - Lincoln DigitalCommons@University of Nebraska - Lincoln

USGS Staff -- Published Research

US Geological Survey

2002

\title{
HIBAL: a hydrologic-isotopic-balance model for application to paleolake systems
}

Larry Benson

University of Colorado at Boulder, great.basin666@gmail.com

Fred Paillet

US Geological Survey

Follow this and additional works at: http:// digitalcommons.unl.edu/usgsstaffpub

Benson, Larry and Paillet, Fred, "HIBAL: a hydrologic-isotopic-balance model for application to paleolake systems" (2002). USGS Staff -- Published Research. 784.

http:// digitalcommons.unl.edu/usgsstaffpub/784

This Article is brought to you for free and open access by the US Geological Survey at DigitalCommons@University of Nebraska - Lincoln. It has been accepted for inclusion in USGS Staff -- Published Research by an authorized administrator of DigitalCommons@University of Nebraska - Lincoln. 


\title{
HIBAL: a hydrologic-isotopic-balance model for application to paleolake systems
}

\author{
Larry Benson $^{\mathrm{a}, *}$, Fred Paillet ${ }^{\mathrm{b}}$ \\ ${ }^{a}$ US Geological Survey, 3215 Marine Street, Boulder, CO 80303, USA \\ ${ }^{\mathrm{b}}$ US Geological Survey, MS 403, Denver Federal Center, Lakewood, CO 80225, USA
}

Received 18 May 2001; accepted 30 August 2001

\begin{abstract}
A simple hydrologic-isotopic-balance (HIBAL) model for application to paleolake $\delta^{18} \mathrm{O}$ records is presented. Inputs to the model include discharge, on-lake precipitation, evaporation, and the $\delta^{18} \mathrm{O}$ values of these fluid fluxes. Monthly values of climatic parameters that govern the fractionation of ${ }^{18} \mathrm{O}$ and ${ }^{16} \mathrm{O}$ during evaporation have been extracted from historical data sets and held constant in the model. The ability of the model to simulate changes in the hydrologic balance and the $\delta^{18} \mathrm{O}$ evolution of the mixed layer has been demonstrated using measured data from Pyramid Lake, Nevada. Simulations of the response in $\delta^{18} \mathrm{O}$ to step- and periodic-function changes in fluid inputs indicate that the hydrologic balance and $\delta^{18} \mathrm{O}$ values lag climate change. Input of reconstructed river discharges and their $\delta^{18} \mathrm{O}$ values to Pyramid and Walker lakes indicates that minima and maxima in simulated $\delta^{18} \mathrm{O}$ records correspond to minima and maxima in the reconstructed volume records and that the overall shape of the volume and $\delta^{18} \mathrm{O}$ records is similar. The model was also used in a simulation of abrupt oscillations in the $\delta^{18} \mathrm{O}$ values of paleo-Owens Lake, California. Published by Elsevier Science Ltd.
\end{abstract}

\section{Introduction}

This paper consists of three separate but linked sections. In this, the first section, we discuss concepts in modeling, previous applications of $\delta^{18} \mathrm{O}$ models, and introduce the hydrologic-isotopic-balance (HIBAL) model, details of which are provided in Appendix A. The second section consists of four parts. First, HIBAL is validated in a simulation of the measured $\delta^{18} \mathrm{O}$ evolution of Pyramid Lake surface water between 1985 and 1994. Second, a series of simulations are done that illustrate the effect of hydrologic closure and overflow of Pyramid Lake on its $\delta^{18} \mathrm{O}$ value. Third, simulations of the response of lake volume and $\delta^{18} \mathrm{O}$ to periodic changes in river discharge are done to assess the degree to which changes in $\delta^{18} \mathrm{O}$ lag climate forcing. Fourth, HIBAL is used in historical simulations of the response of two different lake systems, Pyramid and Walker lakes, to nearly identical climate forcings. In the last section of the paper, we apply the model to paleo-Owens Lake, showing that abrupt changes in the $\delta^{18} \mathrm{O}$ record

\footnotetext{
*Corresponding author. Tel.: +1-303-541-3005; fax: + 1-303-4472505.

E-mail address: lbenson@usgs.gov (L. Benson).
}

can be simulated in model runs that invoke stepfunction changes in the hydrologic state (open or closed) of the lake basin.

\subsection{Concepts in modeling}

The $\delta^{18} \mathrm{O}$ value of a lake is the sum of its sources and sinks and the $\delta^{18} \mathrm{O}$ value of water vapor leaving the lake is strongly influenced by its local climate. In the case of lakes with watersheds in distant mountains, the climate of the watershed also influences the $\delta^{18} \mathrm{O}$ value of the lake through its effect on the $\delta^{18} \mathrm{O}$ value of surface-water input. In such watersheds, the value of precipitation is not constant over time, being a function of the history of the air parcel that carries the precipitation and the temperature at which the precipitation condenses. In addition, the $\delta^{18} \mathrm{O}$ value of watershed precipitation may differ substantially from the $\delta^{18} \mathrm{O}$ value of on-lake precipitation.

Paleolake records of $\delta^{18} \mathrm{O}$ are stored in carbonate precipitates. Given the fact that $\delta^{18} \mathrm{O}$ records represent a complex integration of the elements of climate change, how do we unravel climate history from the $\delta^{18} \mathrm{O}$ record? We must confront the fact that we are dealing 
with a highly underdetermined system, and that to approximate the history of climate change from the $\delta^{18} \mathrm{O}$ record we must make a number of assumptions regarding the nature of the climate system. The implication of this procedure is that no particular solution will be unique. In some cases, additional information on the climate system may be available from other types of climate records, thereby eliminating part of the uncertainty implicit in the modeling exercise. However, many climate proxies are poorly calibrated and a multiproxy approach may often introduce as many unknowns as solutions into the calibration equation set.

A question the modeler must initially address is whether simulations of the entire $\delta^{18} \mathrm{O}$ record will be attempted or whether simulations will be confined to "interesting" parts of the record. The latter strategy has a much higher chance of success in that some climate parameters tend to be relatively stable over short time periods, and thus there is justification for holding these parameters constant in the model. Models can also be used to catalog the response of $\delta^{18} \mathrm{O}$ to various hypothetical climatic transitions. In this mode, the model can be run a number of times to test the sensitivity of $\delta^{18} \mathrm{O}$ to initial conditions, lake-basin geometry, discharge rates, and overflow rates.

It is of paramount importance that the modeler has a thorough understanding of the system that is being simulated. Historic climatic, hydrologic, physical, and chemical data sets can be used to determine the variability of various parameters over annual- and multi-decadal-time scales and their mutual interdependencies. Historical data are also needed to validate the model. The model can be run eliminating or holding constant parameters that will not be available when simulating paleo- $\delta^{18} \mathrm{O}$ records. In this manner, limitations of the model can be exposed.

One of the great difficulties in the use of HIBAL models to estimate past changes in the hydrologic balance of a lake system is that past values of climatic parameters must be assigned to the model. For lake systems, we must exactly know the components of past climates that govern lake evaporation, inflow, and onlake precipitation in order to reconstruct past changes in the hydrologic balance. This indicates that all lakemodeling systems are mathematically underdetermined, forcing the modeler to make assumptions about the nature of the past climate system. In the application of our HIBAL model, we assume that the seasonal cycle of climate in low-elevation lake basins has remained constant. The model has, therefore, been assigned constant monthly mean values of measured climatic parameters. This implies that monthly evaporation rates and values of the evaporation fractionation factor remain constant from year to year.

\subsection{Previous applications of $\delta^{18} \mathrm{O}$ models}

High-resolution $\delta^{18} \mathrm{O}$ records are increasingly being used as proxies of change in climate and hydrologic balance of paleo surface-water systems (e.g., Johnson et al., 1991; Lister et al., 1991; Fontes et al., 1993; Oviatt et al., 1994; Phillips et al., 1994; Hodell et al., 1995; Benson et al., 1997; Li and Ku, 1997; Xia et al., 1997; Benson, 1999; Benson et al., 2001). Variation in $\delta^{18} \mathrm{O}$ values of carbonates precipitated from temperate-region lakes with low-residence times and minimal evaporation losses have generally been attributed to variation in the $\delta^{18} \mathrm{O}$ of precipitation falling in the watershed area of the lake (Stuiver, 1968, 1970; Fritz et al., 1975). Because the $\delta^{18} \mathrm{O}$ of precipitation is highly correlated with air temperature (Yurtsever, 1975), changes in the $\delta^{18} \mathrm{O}$ value of low-residence-time lakes has, therefore, been associated with changes in air temperature (Eicher and Siegenthaler, 1976; Eicher, 1980). In contrast, for lake systems that are hydrologically closed or have long or intermediate residence times, emphasis has often been placed on change in the hydrologic balance as the principal process responsible for $\delta^{18} \mathrm{O}$ variability (Johnson et al., 1991; Lister et al., 1991; Fontes et al., 1993; Oviatt et al., 1994; Phillips et al., 1994; Hodell et al., 1995; Benson, 1999).

Numerical modeling of the behavior of $\delta^{18} \mathrm{O}$ has usually been confined to simulations of the measured $\delta^{18} \mathrm{O}$ variability in lake water (e.g., Gat, 1970; Lewis, 1979; Hostetler and Benson, 1994). Phillips et al. (1994) have applied a lumped-parameter model (Phillips et al., $1986,1992)$ in an attempt to reproduce a mid-to-lateWisconsin $\delta^{18} \mathrm{O}$ record from the Searles Lake basin, California.

Hostetler and Benson (1994) coupled the isotopic derivations later published in Benson and White (1994) to a one-dimensional thermal model developed by Hostetler and Bartlein (1990). The coupled model was used to simulate the $\delta^{18} \mathrm{O}$ structure of Pyramid Lake for the period 1985-1991. The system was well determined. Inputs to the model included daily values of meteorological and lake-thermal data (Hostetler and Benson, 1993). Daily discharges of the Truckee River were obtained from US Geological Survey Water-Data Reports (1986-1992) and isotopic data sets were available for Truckee River input and Pyramid Lake surface water on a monthly or better frequency (Benson, 1994). Pyramid Lake $\delta^{18} \mathrm{O}$ profiles were available for most months of the simulation and the $\delta^{18} \mathrm{O}$ value of advected air was determined from a limited number of field experiments in which vapor-phase extractions were conducted (Benson and White, 1994).

Both wind-driven turbulent mixing (eddy diffusion) and density-driven convective mixing were simulated in the model which divided Pyramid Lake into 1-mthick layers. Transport of oxygen isotopes (within the 
water molecule) was accomplished by eddies and convection without preference for isotopic species $\left({ }^{18} \mathrm{O}\right.$ and ${ }^{16} \mathrm{O}$ ).

Because the fraction of advected air $\left(f_{\text {ad }}\right)$ was not measured, it was used as an adjustable parameter in the simulations. Successful simulations were made using a daily time step with $f_{\text {ad }}$ set to 0.1 for the periods October 1987 to October 1989 and from May 1991 through December 1991 (Figs. 3 and 4 in Hostetler and Benson, 1994). A $6.5 \mathrm{yr}$ simulation also was made using a monthly time step and monthly values of river discharge, on-lake precipitation, and their $\delta^{18} \mathrm{O}$ values (Benson, 1994). Monthly inputs of lake-surface temperature, relative humidity, evaporation rate, and depth of the mixed layer were approximated by averaging the output from the 1987 to 1989 daily simulations. The model reproduced the trend in $\delta^{18} \mathrm{O}$ between 1986 and 1992, but in some cases underestimated the magnitude of seasonal fluctuations in surface $\delta^{18} \mathrm{O}$ values (Fig. 1). The inability of the model to reproduce seasonal $\delta^{18} \mathrm{O}$ variability is thought to result from two factors. Use of mean-monthly mixed-layer thicknesses is probably a poor approximation for very wet and very dry years, and during very wet years, a thin layer of isotopically light discharge water can persist on the surface of the mixed layer (meromixis). Thus, measured $\delta^{18} \mathrm{O}$ values of the surface layer were not representative of the mean $\delta^{18} \mathrm{O}$ value of the mixed layer.

The model successfully demonstrated that monthly averages of measured daily data obtained during a short time period $(2 \mathrm{yr})$ could be applied in model simulations that ran for several years when the lake was hydrologically closed and ice free.

The purpose of this paper is the introduction of a relatively simple HIBAL model that can be used to

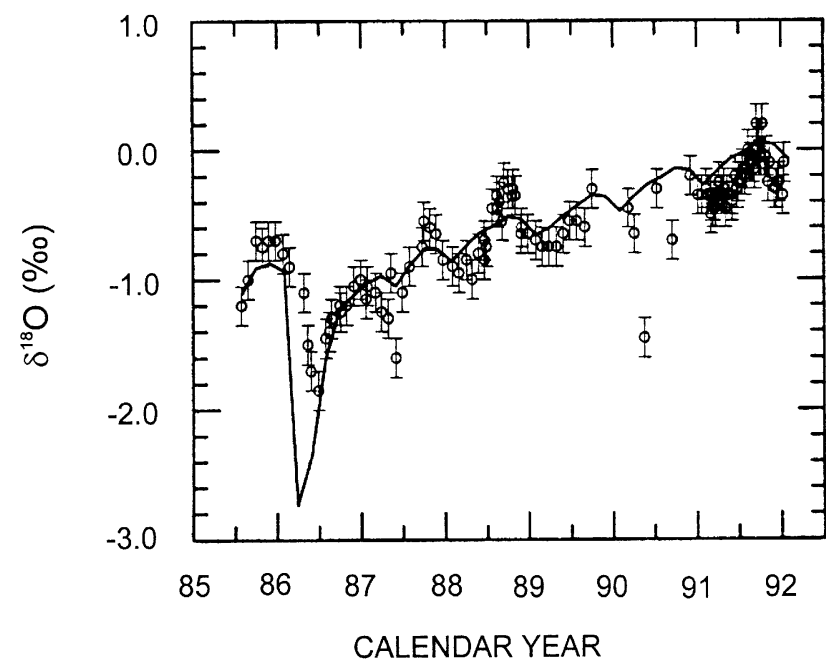

Fig. 1. Simulated epilimnetic (mixed layer) $\delta^{18} \mathrm{O}$ values for Pyramid Lake (solid line) compared with 1985 to 1992 measured values (Benson, 1994; Hostetler and Benson, 1994). evaluate $\delta^{18} \mathrm{O}$ records recovered from mid-latitude paleolake systems. HIBAL is a two-box model that runs on a monthly time step. Model inputs are fluid fluxes and their $\delta^{18} \mathrm{O}$ values, depth of the mixed layer, basin hypsometry, and a set of meteorological data that govern the fractionation of $\delta^{18} \mathrm{O}$ during evaporation (i.e., air temperature, water temperature, relative humidity, wind speed, and the fraction and $\delta^{18} \mathrm{O}$ value of air advected over the lake surface) and precipitation of $\mathrm{CaCO}_{3}$ (water temperature). The structure of and inputs to the model are discussed fully in Appendix A.

\section{Validation and applications of HIBAL using historical data sets}

\subsection{Simulation of Pyramid Lake historical (1916-1997) volume}

In order to determine if the hydrologic balance of Pyramid Lake could be simulated using fixed meanannual values of evaporation and on-lake precipitation, we used estimated values of these parameters (1.20 and $0.18 \mathrm{~m} \mathrm{yr}^{-1}$, see Appendix A), together with estimated values of Truckee River discharge at the Nixon gage (Fig. 2), to calculate the change in Pyramid Lake volume between 1916 and 1997. The simulated lake-volume record was a close match to the historical record (Fig. 3).

\subsection{Simulation of Pyramid Lake surface-water $\delta^{18} \mathrm{O}$ between 1985 and 1994}

The Truckee River-Pyramid Lake surface-water system has been the object of intensive hydrologic, chemical, isotopic, and biological studies during the past several decades. The system is complicated by storage in natural lakes (Tahoe, Donner, and Independence lakes) and man-made upstream reservoirs (Prosser, Boca, and Stampede reservoirs) and by river diversion at the Derby Dam (Fig. 2). Cold-season precipitation falling in the Sierra Nevada is released to the Truckee River surfacewater system as snowmelt in the spring and early summer. Approximately $32 \%$ of Truckee River flow reaching the Farad gage in eastern California originates from overflow of Lake Tahoe and 38\% of Truckee River flow reaching the Farad gage passes through small-capacity reservoirs. The remaining $30 \%$ of the flow enters the river as surface and nearsurface flows (Benson, 1994). Above Farad, the Truckee River is largely unaffected by diversion and downstream contributions of water are small. Groundwater input to Pyramid Lake is negligible. Prior to 1917 , overflow to Winnemucca Lake occurred frequently. 


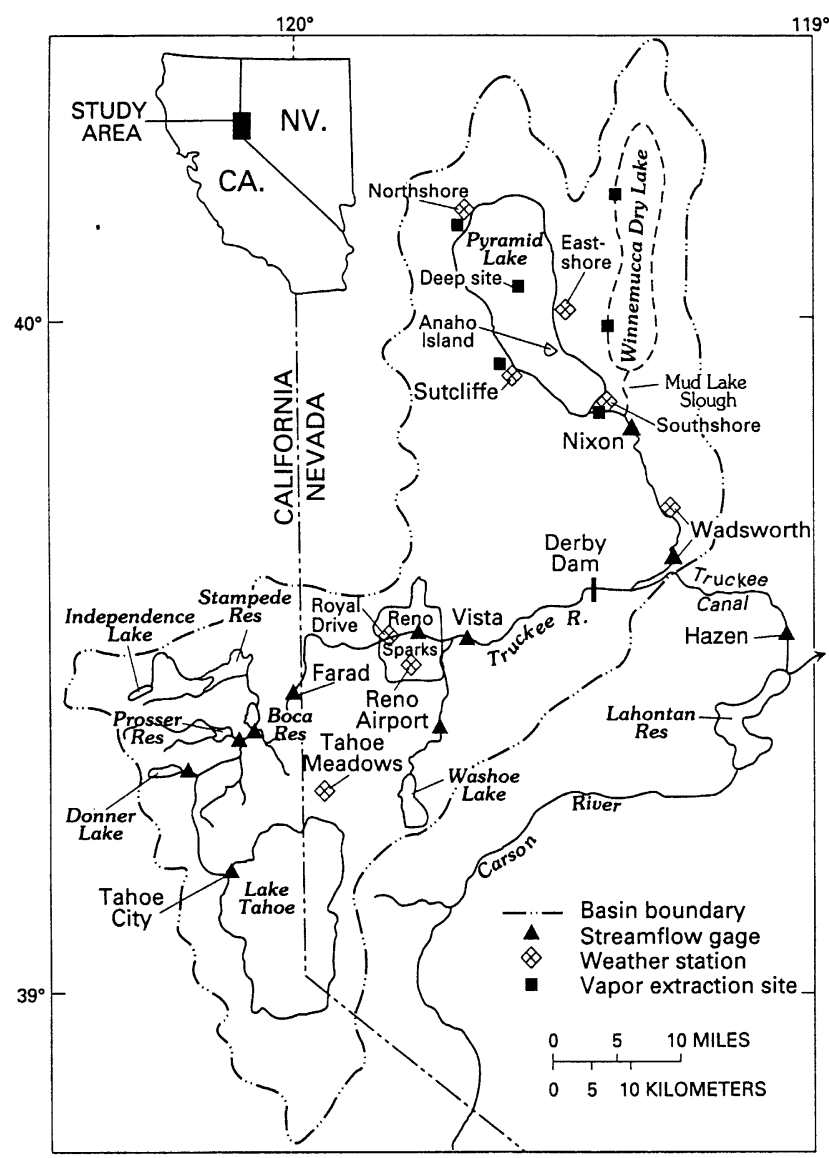

Fig. 2. Pyramid Lake surface-water system showing location of streamflow gages, weather stations, and temperature profile site (Deep site).

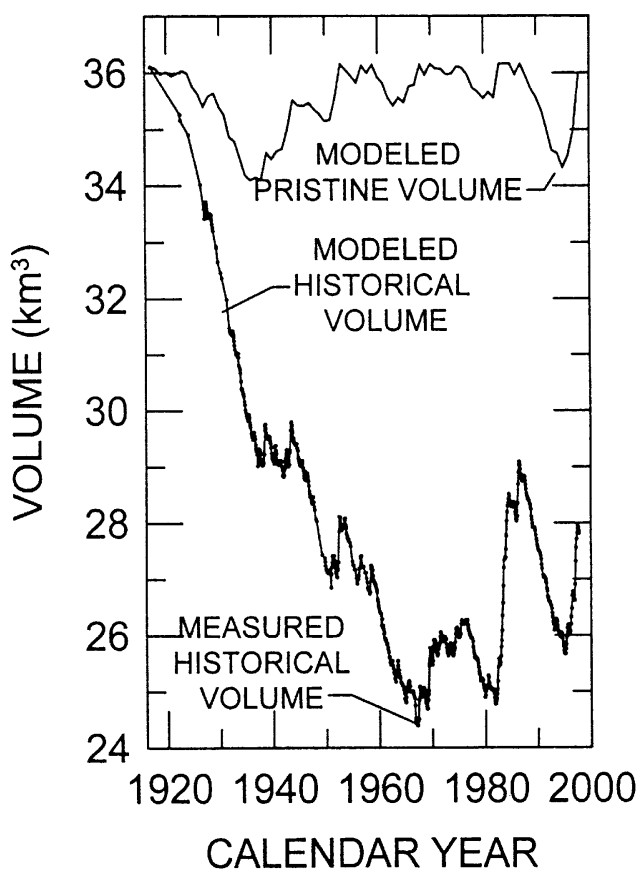

Fig. 3. Pyramid Lake measured volume (1916-1997) compared with model simulations using Nixon flow data (modeled historical volume) and Farad flow data (modeled pristine volume).
In 1906, Derby Dam, located $53 \mathrm{~km}$ upstream of Pyramid Lake, was completed. Since that time, an average of $54 \%$ of Truckee River flow has been diverted from the Truckee River basin, causing the level of Pyramid Lake to rapidly decline. Because of the decreases in inflow, Pyramid Lake has not overflowed to the Winnemucca Lake basin since 1917 ; it has remained hydrologically closed for the past $83 \mathrm{yr}$.

We used HIBAL to simulate the measured $\delta^{18} \mathrm{O}$ evolution of the mixed layer in Pyramid Lake between 1985 and 1994. For this simulation, we used an initial $\delta^{18} \mathrm{O}$ value of $-1.2 \%$, an initial (January 1985) lake elevation of $1161.9 \mathrm{~m}$, a constant annual on-lake precipitation rate of $0.18 \mathrm{~m} \mathrm{yr}^{-1}$, and a constant annual evaporation rate of $1.20 \mathrm{~m} \mathrm{yr}^{-1}$. For this and other simulations of the evolution of Pyramid Lake $\delta^{18} \mathrm{O}$, it was assumed that Lake Tahoe contributed $33 \%$ of the input to the Truckee River. Although HIBAL failed to capture the full variability of the annual cycle over the $8.5 \mathrm{yr}$ period, the simulated trend in $\delta^{18} \mathrm{O}$ values of the mixed layer $\left(\delta>{ }^{18} \mathrm{O}_{\text {lake }}\right)$ is similar to the measured data (Fig. 4) and also to the simulations of Hostetler and Benson (1994) (Fig. 1).

\subsection{Response of Pyramid Lake $\delta^{18} O$ to changes in annual Truckee River discharge}

Several $500 \mathrm{yr}$ simulations were made with HIBAL to illustrate the effect of hydrologic closure and overflow of Pyramid Lake on its $\delta^{18} \mathrm{O}$ value (Fig. 5, Table 1). In all

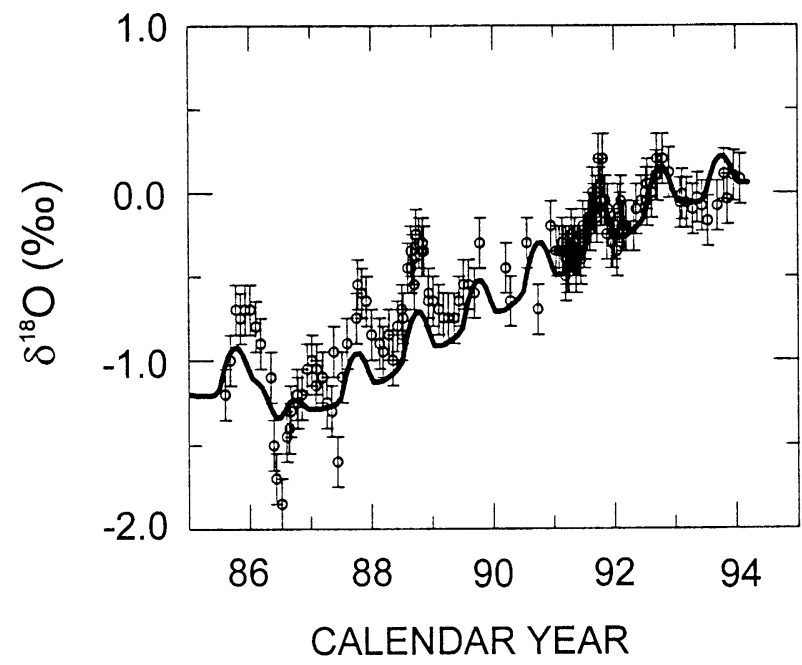

Fig. 4. HIBAL simulation of the $\delta^{18} \mathrm{O}$ evolution of surface waters of Pyramid Lake between 1985 and 1994. Much of the warm-season difference between simulated and measured values of $\delta^{18} \mathrm{O}$ may be attributable to the fact that the model simulates the $\delta^{18} \mathrm{O}$ value of a well-mixed epilimnion, but the measured $\delta^{18} \mathrm{O}$ values were taken from the surface of the epilimnion which may be strongly affected by isotopic fractionation during evaporation. 
simulations, the $\delta^{18} \mathrm{O}$ response to a step-function change in the hydrologic balance consists of an initial transient, lasting $\leqslant 100 \mathrm{yr}$, followed by an exponential decay to the steady state. When climate switches to a wetter state, $\delta^{18} \mathrm{O}$ values first decrease, reflecting the initial dominance of discharge over evaporation on the hydrologic and isotopic balances. In situations in which climate suddenly switches to a drier state, $\delta^{18} \mathrm{O}$ values first increase, reflecting the initial dominance of evaporation over discharge on the hydrologic and isotopic balances, then the $\delta^{18} \mathrm{O}$ values slowly decay to their steady-state value.

For three of the four overflow simulations, initial lake depth was set to $100 \mathrm{~m}$ ( $23 \mathrm{~m}$ below Pyramid Lake's spill point), $\delta^{18} \mathrm{O}_{\text {lake }}$ was set to $0.0 \%$, and discharge of the Truckee River $\left(D_{\mathrm{TR}}\right)$ was set to $0.60,0.70$ (the historical mean value), and $0.80 \mathrm{~km}^{3} \mathrm{yr}^{-1}$. In these simulations, the total input $\left(V_{\text {in }}\right)$ to Pyramid Lake increased from 0.71 to $0.91 \mathrm{~km}^{3} \mathrm{yr}^{-1}$. Results of the simulations indicate a progressive decrease in the steady-state value of $\delta^{18} \mathrm{O}_{\text {lake }}$ with increasing fluid input to Pyramid Lake (increasing overflow to the Winnemucca Lake basin) (Fig. 5A, Table 1). In the fourth overflow simulation, $D_{\text {TR }}$ was set to $0.70 \mathrm{~km}^{3} \mathrm{yr}^{-1}$ and initial lake depth was set to $40 \mathrm{~m}$ ( $83 \mathrm{~m}$ below the spill point). The negative $4.1 \%$ transient in $\delta^{18} \mathrm{O}_{\text {lake }}$ indicates the effect of dumping a large volume of isotopically light river water into a small-volume lake.

In two of the three simulations that tested the response of a hydrologically closed Pyramid Lake to a step-function change in the hydrologic balance, Lake Tahoe was allowed to contribute one third of the inflow
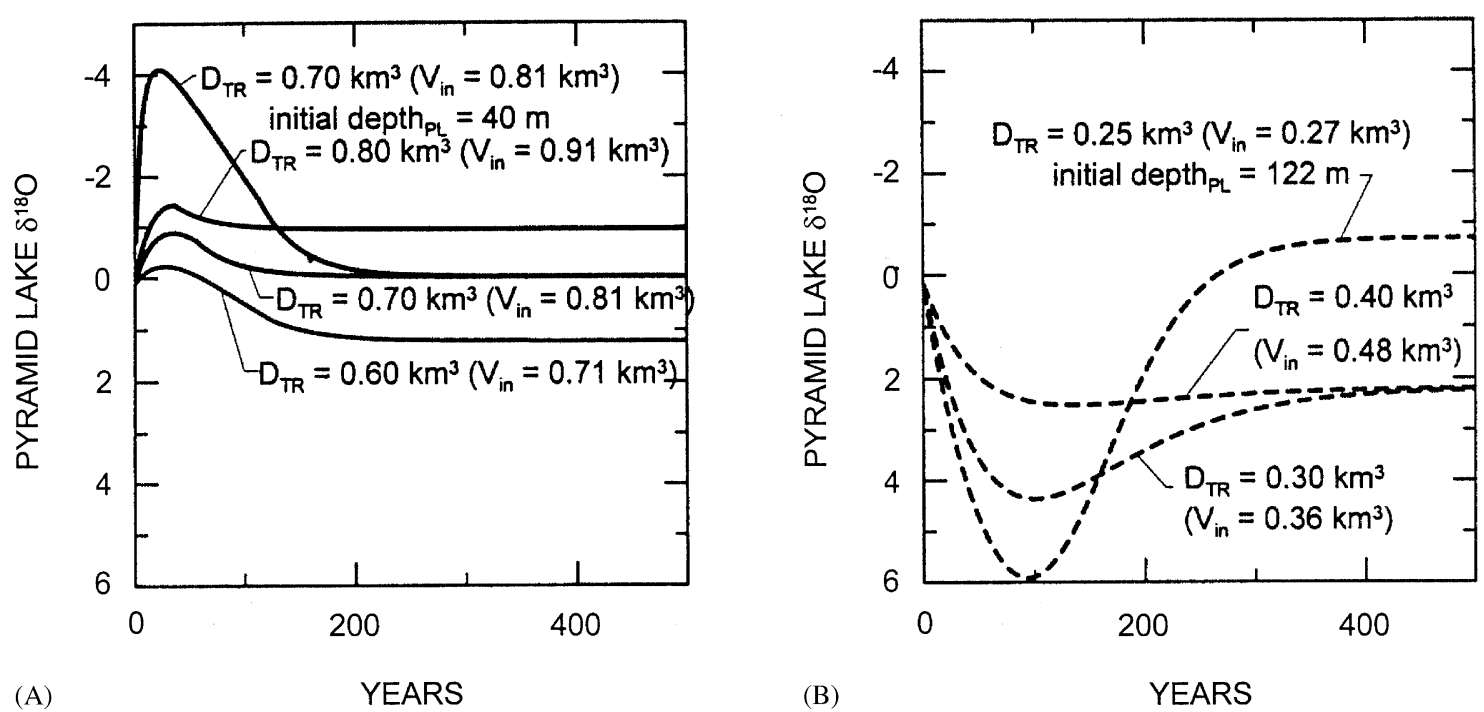

Fig. 5. HIBAL simulations of the response of $\delta^{18} \mathrm{O}$ to step-function perturbations in climate (input). (A) Simulations in which Pyramid Lake overflows. (B) Simulations in which Pyramid Lake is hydrologically closed. The $\delta^{18} \mathrm{O}$ response is characterized by an initial transient whose magnitude is proportional to the input volume: lake volume ratio weighted by their respective $\delta^{18} \mathrm{O}$ values. The steady-state $\delta^{18} \mathrm{O}$ value in the hydrologically open simulations is proportional to the overflow volume: lake volume ratio. Under hydrologically closed conditions, the steady-state $\delta^{18} \mathrm{O}$ value of the lake is equal to the input $\delta^{18} \mathrm{O}$ value minus the output $\delta^{18} \mathrm{O}$ value.

Table 1

Input data and results of simulations of Pyramid Lake $\delta^{18} \mathrm{O}$ response to changes in Truckee River discharge ${ }^{\mathrm{a}}$

\begin{tabular}{|c|c|c|c|c|c|c|c|c|c|}
\hline$d_{\mathrm{i}}(\mathrm{m})$ & $\delta^{18} \mathrm{O}_{\mathrm{i}}(\% 0)$ & $D\left(\mathrm{~km}^{3} \mathrm{yr}^{-1}\right)$ & $\delta^{18} \mathrm{O}_{\mathrm{TR}}(\%)$ & $P_{\mathrm{ol}}(\mathrm{m})$ & $\delta^{18} \mathrm{O}_{\mathrm{ol}}(\%)$ & $E(\mathrm{~m})$ & $V_{\text {in }}\left(\mathrm{km}^{3} \mathrm{yr}^{-1}\right)$ & $\delta^{18} \mathrm{O}_{\text {trans }}(\%)$ & $\delta^{18} \mathrm{O}_{\mathrm{SS}}(\%)$ \\
\hline \multicolumn{10}{|c|}{ Hydrologically open simulations } \\
\hline 100 & 0.0 & 0.60 & -11.6 & 0.20 & -10.6 & 1.20 & 0.71 & -0.3 & 1.2 \\
\hline 100 & 0.0 & 0.70 & -11.6 & 0.20 & -10.6 & 1.20 & 0.81 & -0.9 & 0.0 \\
\hline 100 & 0.0 & 0.80 & -11.6 & 0.20 & -10.6 & 1.20 & 0.91 & -1.5 & -1.0 \\
\hline 40 & 0.0 & 0.70 & -11.6 & 0.20 & -10.6 & 1.20 & 0.81 & -4.1 & 0.0 \\
\hline \multicolumn{10}{|c|}{ Hydrologically closed simulations } \\
\hline 100 & 0.0 & 0.30 & -11.6 & 0.20 & -10.6 & 1.20 & 0.36 & 2.5 & 2.2 \\
\hline 100 & 0.0 & 0.40 & -11.6 & 0.20 & -10.6 & 1.20 & 0.48 & 4.2 & 2.2 \\
\hline 122 & 0.0 & 0.25 & -14.6 & 0.20 & -10.6 & 1.20 & 0.27 & 6.0 & -0.8 \\
\hline
\end{tabular}

${ }^{\mathrm{a}} d_{\mathrm{i}}$, initial lake depth; $\delta^{18} \mathrm{O}_{\mathrm{i}}$, initial lake $\delta^{18} \mathrm{O} ; D$, Truckee River discharge; $\delta^{18} \mathrm{O}_{\mathrm{TR}}$, Truckee River $\delta^{18} \mathrm{O} ; P_{\mathrm{ol}}$, on-lake precipitation; $\delta^{18} \mathrm{O}_{\mathrm{ol}}$, on-lake precipitation $\delta^{18} \mathrm{O} ; E$, evaporation; $V_{\text {in }}$, total input to Pyramid Lake; $\delta^{18} \mathrm{O}_{\text {trans }}$, initial transient in $\delta^{18} \mathrm{O} ; \delta^{18} \mathrm{O}_{\mathrm{SS}}$, steady state value of Pyramid Lake $\delta^{18} \mathrm{O}$. 
to Pyramid Lake. Initial lake depth was set to $100 \mathrm{~m}$, $\delta^{18} \mathrm{O}_{\text {lake }}$ was set to $0.0 \%$, and $D_{\mathrm{TR}}$ was set to 0.30 and $0.40 \mathrm{~km}^{3} \mathrm{yr}^{-1}$ (Fig. 5B, Table 1). The steady-state $\delta^{18} \mathrm{O}$ value achieved in both simulations was exactly the same $(2.2 \%)$, illustrating that under closed-basin conditions the $\delta^{18} \mathrm{O}_{\text {lake }}$ value is dependent only on the difference between the $\delta^{18} \mathrm{O}$ values of inflow $\left(\delta^{18} \mathrm{O}_{\text {in }}=-11.6 \%\right.$ ) and the evaporation fractionation factor $\left(\delta^{18} \mathrm{O}_{\text {evap }}-\right.$ $\delta^{18} \mathrm{O}_{\text {lake }}=-13.8 \%$ o) .

In order to determine the response of Pyramid Lake $\delta^{18} \mathrm{O}$ to severe drought sufficient to cause Lake Tahoe to fall below its spill point, the depth of Pyramid Lake was set to $122 \mathrm{~m}$ and $D_{\mathrm{TR}}$ was set to a value of $0.25 \mathrm{~km}^{3} \mathrm{yr}^{-1}$. The results of this simulation indicate that $\delta^{18} \mathrm{O}$ initially experiences a $6.0 \%$ o transient before achieving a steady state value of $-0.8 \%$. In this simulation, the steady-state $\delta^{18} \mathrm{O}$ value was negatively shifted $3.0 \%$ relative to the results of the other two closed-basin simulations (Fig. 5B, Table 1). This shift reflects the loss of isotopically heavy Lake Tahoe input to the Truckee River system; i.e., $\delta^{18} \mathrm{O}_{\text {in }}$ was $3.0 \%$ less $(-11.6$ to $14.6 \%$ ) with closure of Lake Tahoe.

\subsection{Lags in the response of Pyramid Lake volume and $\delta^{18} \mathrm{O}$ to climate change}

Simulations of the response of lake volume and $\delta^{18} \mathrm{O}$ to periodic climate forcing (changes in river discharge) were made in order to assess how much $\delta^{18} \mathrm{O}$ lags climate change, and the degree to which $\delta^{18} \mathrm{O}$ mimics the shape of the climate forcing. Two sets of simulations were made under hydrologically open (Fig. 6) and hydrologically closed conditions (Fig. 7). We used the following periodic function to generate discharge wavelengths of 10,50 , and $100 \mathrm{yr}$ and an amplitude of $0.1 \mathrm{~km}^{3}$ :

$y=A_{\max } \sin \frac{2 \pi t}{\lambda}+D$,

where $y$ is the discharge in $\mathrm{km}^{3}, A_{\max }$ the maximum amplitude in $\mathrm{km}^{3}, t$ the time in $\mathrm{yr}, \lambda$ the wavelength in $\mathrm{yr}$, and $D_{\text {in }}$ the mean discharge in $\mathrm{km}^{3} \mathrm{yr}^{-1}$.

Pyramid Lake overflows when $V_{\text {in }}=D_{\text {in }}>0.58$; therefore, $D_{\text {in }}$ was varied between 0.63 and $0.73 \mathrm{~km}^{3} \mathrm{yr}^{-1}$ in the open-system simulations. The results of these simulations indicate that $\delta^{18} \mathrm{O}$ and volume responses were nearly identical, and that both responses lagged discharge periodicities of 10,50 , and $100 \mathrm{yr}$ by $1.5,11$, and $15 \mathrm{yr}$ (Fig. $6 \mathrm{~A}-\mathrm{C}$ ). Thus the $\delta^{18} \mathrm{O}$ lag time varied from $\sim 15$ to $\sim 20 \%$ of the period of climate forcing.

For the closed-system simulations, $D_{\text {in }}$ was varied between 0.30 and $0.40 \mathrm{~km}^{3} \mathrm{yr}^{-1}$. The $\delta^{18} \mathrm{O}$ lag time also varied from $\sim 15$ to $\sim 20 \%$ of the period of climate forcing in these simulations (Fig. 7A-C). Comparison of the composite forcing (discharge data) with the composite $\delta^{18} \mathrm{O}$ response (Figs. 6D and 7D) indicates a great deal of similarity in the overall shape of the forcing and response functions. The high-frequency responses, however, were not nearly as variable as the high-frequency forcing.

\subsection{Comparison of reconstructed $\delta^{18} \mathrm{O}$ and lake-volume records for Pyramid and Walker Lakes, Nevada}

To this point we have examined the modeled response of $\delta^{18} \mathrm{O}$ to hypothetical step-function and periodic changes in the hydrologic balance under either hydrologically closed or hydrologically open conditions. In this section, we use reconstructed discharges of the Truckee (Benson et al., 2001) and Walker rivers (Milne, 1987) to simulate pristine volume and aragonite $\left(\delta^{18} \mathrm{O}_{\mathrm{CaCO}_{3}}\right)$ records for Pyramid and Walker lakes since 1916 (Fig. 8). With pristine (reconstructed) flows, Walker Lake would have remained a hydrologically closed system, but Pyramid Lake would have shifted from open to closed conditions when its level dropped below $1177 \mathrm{~m}$ and its volume fell below $36.2 \mathrm{~km}^{3}$. It is apparent from its reconstructed lake-volume record that Pyramid Lake would have fallen below its spill point during severe droughts that occurred during the late 1920 s and throughout the 1930s, during the late 1940s and early 1950s, during the early 1960s and late 1970s, and during the late 1980s and early 1990s (Fig. 8A). Each of these droughts is also indicated as minima in the Walker Lake volume record.

Walker Lake has a geographic setting similar to Pyramid Lake. It is fed by a single stream (Walker River) which also receives its moisture from Sierran snowmelt. Reconstructed annual discharges of the Walker River to Walker Lake average $0.38 \mathrm{~km}^{3} \mathrm{yr}^{-1}$ and are available from 1871 to 1986 (Milne, 1987). The evaporation rate for Walker Lake $\left(1.3 \mathrm{~m} \mathrm{yr}^{-1}\right)$ is similar to that of Pyramid Lake $\left(1.2 \mathrm{~m} \mathrm{yr}^{-1}\right)$, and for the simulation of the historical $\delta^{18} \mathrm{O}$ evolution of Walker Lake, we used identical climatic, isotopic, and hydrologic inputs (excepting discharge). The initial depth of Walker Lake was set to its 1916 reconstructed value of $86.6 \mathrm{~m}$ and its initial $\delta^{18} \mathrm{O}$ value was set to $-1.0 \%$. In the simulations, $\delta^{18} \mathrm{O}_{\text {lake }}$ was converted to $\delta^{18} \mathrm{O}$ values of a carbonate precipitate $\left(\delta^{18} \mathrm{O}_{\mathrm{CaCO}_{3}}\right)$ using equations from O’Neil et al. (1969).

Comparison of the simulated $\delta^{18} \mathrm{O}_{\mathrm{CaCO}_{3}}$ records for Pyramid and Walker lakes with their reconstructed volumes shows that minima and maxima in $\delta^{18} \mathrm{O}_{\mathrm{CaCO}_{3}}$ occur at the same time as minima and maxima in volume (Fig. 8A, B). This illustrates that $\delta^{18} \mathrm{O}$ is a faithful recorder of the timing and direction of change in the hydrologic balance of both lakes. In addition, the overall shape of the Walker Lake volume and $\delta^{18} \mathrm{O}_{\mathrm{CaCO}_{3}}$ records are remarkably similar, suggesting that even though volume and $\delta^{18} \mathrm{O}$ cannot be linked by an 

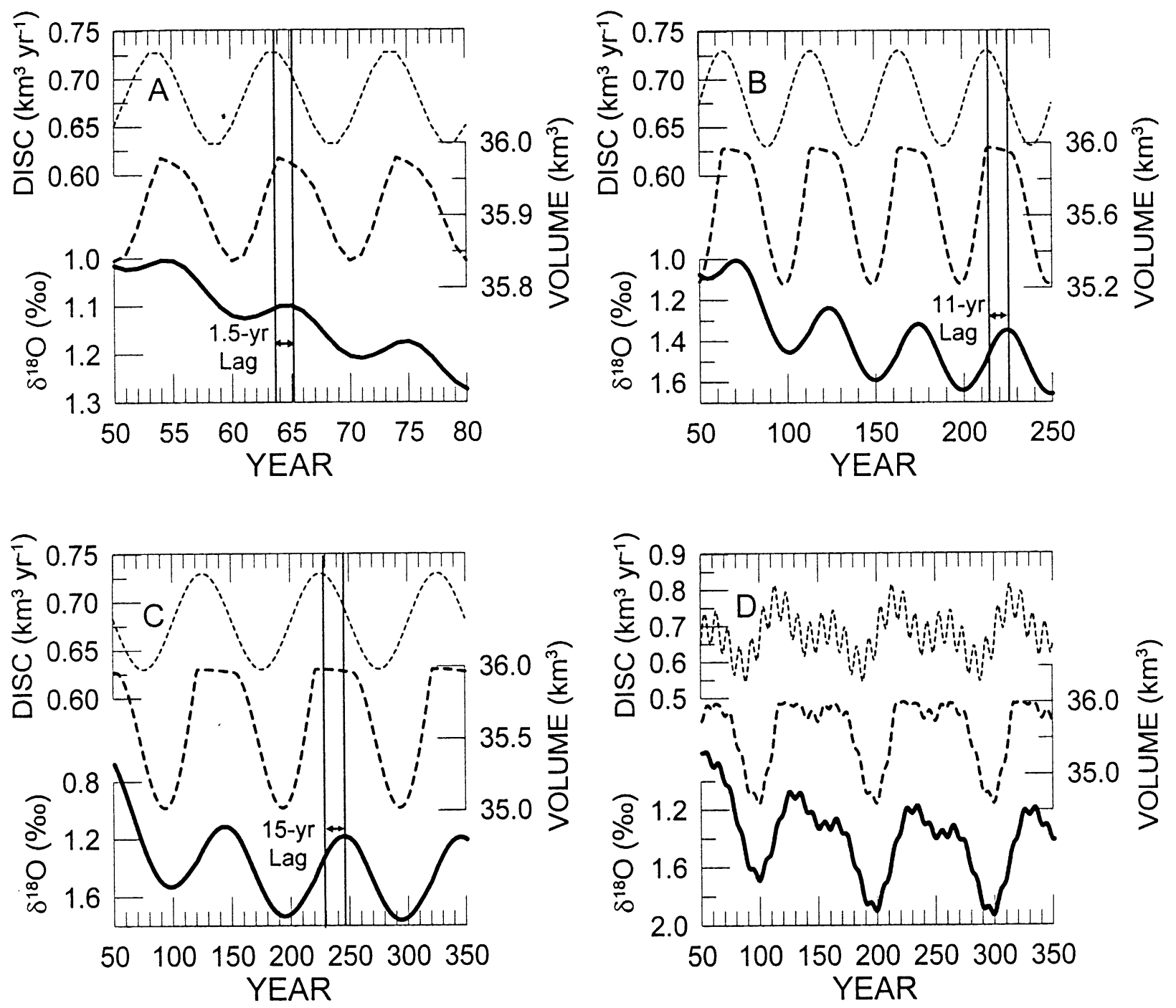

Fig. 6. HIBAL simulations of the response of $\delta^{18} \mathrm{O}$ to periodic perturbations in climate (discharge) under overflow conditions. (A) Perturbations with a $10 \mathrm{yr}$ wavelength. (B) Perturbations with a $50 \mathrm{yr}$ wavelength. (C) Perturbations with a $100 \mathrm{yr}$ wavelength. (D) Composite record of the $10 \mathrm{yr}$, $50 \mathrm{yr}$, and $100 \mathrm{yr}$ perturbations. The $\delta^{18} \mathrm{O}$ records lag the climate perturbations by $15-20 \%$ of the perturbation wavelength, but their form is strongly similar to the form of the perturbation.

equation of state, they do tend to exhibit similar shapes over, at least, decadal time scales. The magnitudes of negative maxima in the Pyramid Lake $\delta^{18} \mathrm{O}_{\mathrm{CaCO}_{3}}$ record are not reflected in the volume record during overflow. This "excess" volume is instead reflected in the amount of water spilled to the adjacent Winnemucca Lake basin.

\section{Applications of HIBAL to a Late Pleistocene $\delta^{18} \mathrm{O}$ record}

\subsection{Simulations of $\delta^{18} \mathrm{O}$ variations in the Owens Lake system during the Pleistocene-Holocene transition}

Between 15 and $10 \mathrm{cal} \mathrm{ka}$ BP, four relatively brief, 6-9\%o oscillations in $\delta^{18} \mathrm{O}$ were recorded in Owens Lake, California (Fig. 9). Benson et al. (1997) have interpreted the oscillations as being caused by abrupt changes in the hydrologic balance of Owens Lake; i.e., its change from a hydrologically open to a hydrologically closed system.

In the following, we used HIBAL to simulate the response of $\delta^{18} \mathrm{O}$ to closure and spill of Owens Lake during the Pleistocene-Holocene transition. Given the paucity of historic and prehistoric climate and lake data sets, we were forced to make several simplifying assumptions, including the following:

(1) When short-lived heavy $\left(\delta^{18} \mathrm{O}_{\mathrm{CaCO}_{3}}>24 \%\right.$ ) excursions in $\delta^{18} \mathrm{O}$ values occurred, we assumed that the climate had been either warm and dry (historic mode) or cold and dry (interstadial mode). For simulations involving the historic mode, we used historic Pyramid Lake climate and lake data sets (Appendix A) because they were the only data 

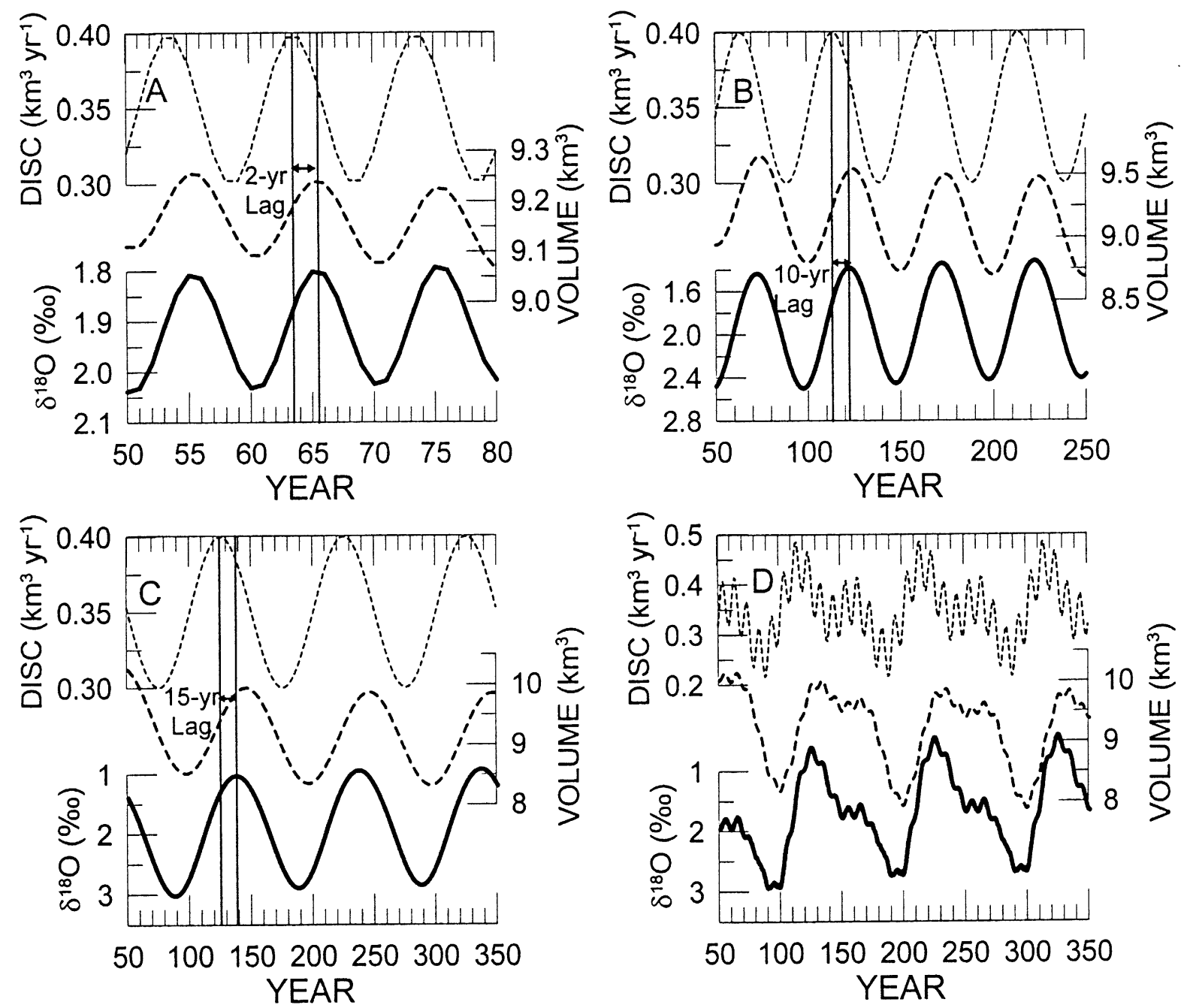

Fig. 7. HIBAL simulations of the response of $\delta^{18} \mathrm{O}$ to periodic perturbations in climate (discharge) under closed-basin conditions. (A) Perturbations with a $10 \mathrm{yr}$ wavelength. (B) Perturbations with a $50 \mathrm{yr}$ wavelength. (C) Perturbations with a $100 \mathrm{yr}$ wavelength. (D) Composite record of the $10 \mathrm{yr}$, $50 \mathrm{yr}$, and $100 \mathrm{yr}$ perturbations. As in the case of an overflowing lake, the $\delta^{18} \mathrm{O}$ records lag the climate perturbations by $15-20 \%$ of the perturbation wavelength, and their form is strongly similar to the form of the perturbation. Note, however, that the high-frequency part of the compositedischarge record is not clearly reproduced in the $\delta^{18} \mathrm{O}$ record.

available and because the climatic settings of Owens and Pyramid Lakes are similar. For the historic mode, Owens Lake evaporation and on-lake precipitation rates were set to their estimated historic values of 1.5 and $0.1 \mathrm{~m} \mathrm{yr}^{-1}$ (Hollett et al., 1991).

(2) When light $\delta^{18} \mathrm{O}$ values (18-21\%) dominated the Owens Lake record, we assumed the climate had been cold and wet (stadial mode). For the cold stades and interstades, we adjusted Pyramid Lake values of air temperature, water temperature, mixed-layer depth, and Owens Lake evaporation and on-lake precipitation rates in accordance with the results of Hostetler and Benson (1994) who simulated the conditions responsible for the rise of late-Pleistocene Lake Lahontan. $7^{\circ} \mathrm{C}$ was subtracted from the Pyramid Lake monthly air-temperature distribution and the water temperature of the coldest and warmest months were set, respectively, to $1{ }^{\circ} \mathrm{C}$ and $14^{\circ} \mathrm{C}$. The temperatures of the intervening months were scaled between these values using the modern distribution of Pyramid Lake water temperatures. In addition, the depth of the mixed layer was reduced to reflect the decrease in heat gained by the lake over the annual cycle. This was accomplished by scaling the depth of the mixed layer to its water temperature using historical relationships (Appendix A). Evaporation rate was set to $0.75 \mathrm{~m} \mathrm{yr}^{-1}$ (about half the Owens Lake historical value) and on-lake precipitation was set to $0.30 \mathrm{~m} \mathrm{yr}^{-1}$ (about three times its historical value).

To simulate the effects of overflow on $\delta^{18} \mathrm{O}_{\mathrm{CaCO}_{3}}$, the initial depth of Owens Lake was set to $10 \mathrm{~m}$ (55 m below 

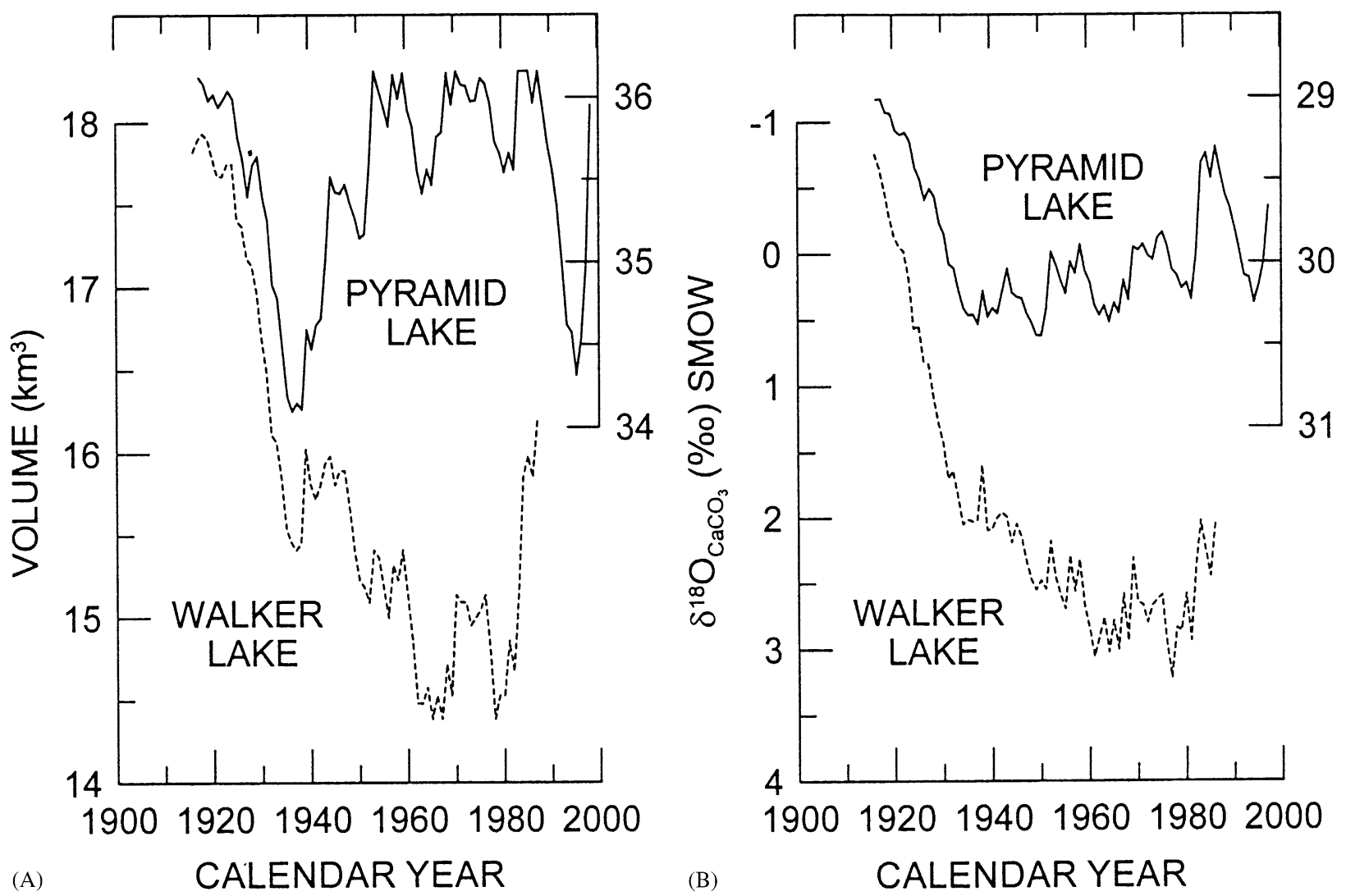

Fig. 8. Reconstructed (A) volume and (B) $\delta^{18} \mathrm{O}$ records for Pyramid and Walker lakes since 1916. Reconstructed discharge for the Walker River used to calculate Walker Lake volumes are available only through1986 (Milne, 1987).

its spill point). The model was then run to simulate the effects of a step-function change to a cold and wet (stadial mode) climate. Three different discharge volumes were input to the model, 0.56, 0.84, and $1.69 \mathrm{~km}^{3} \mathrm{yr}^{-1}$, representing 2, 3, and 6 times the volumes necessary to cause overflow. The model was run for $300 \mathrm{yr}$. The initial $\delta^{18} \mathrm{O}_{\text {lake }}$ value was set to $0.0 \%$, and $\delta^{18} \mathrm{O}$ values of river discharge and on-lake precipitation were set to their stadial values $(-17 \%$, Benson, 1999 , p. 212).

The results of the three simulations (Table 2, Fig. 10A, B, first $300 \mathrm{yr}$ ) indicate an abrupt 10.4 to $13.5 \%$ o decrease in $\delta^{18} \mathrm{O}_{\mathrm{CaCO}_{3}}$, followed by exponential decay over a $100-200 \mathrm{yr}$ interval to steady-state $\delta^{18} \mathrm{O}_{\mathrm{CaCO}_{3}}$ values. The discontinuity in the exponential decay indicates the time that Owens Lake began to overflow. As the volume of the hydrologically closed Owens Lake increases, $\delta^{18} \mathrm{O}_{\text {lake }}$ decreases, reflecting the addition of isotopically light river discharge; the faster the volume increase, the greater the decrease in $\delta^{18} \mathrm{O}_{\text {lake }}$ and the more negative the value of the $\delta^{18} \mathrm{O}$ transient. When Owens Lake overflows, the steady state $\delta^{18} \mathrm{O}$ value of the overflowing lake water is proportional to the ratio of the spill rate $\left(V_{\text {spill }}\right)$ relative to maximum lake volume $\left(V_{\text {lake }}\right)$. This is because the residence time of water in the spilling lake decreases with increased rate of

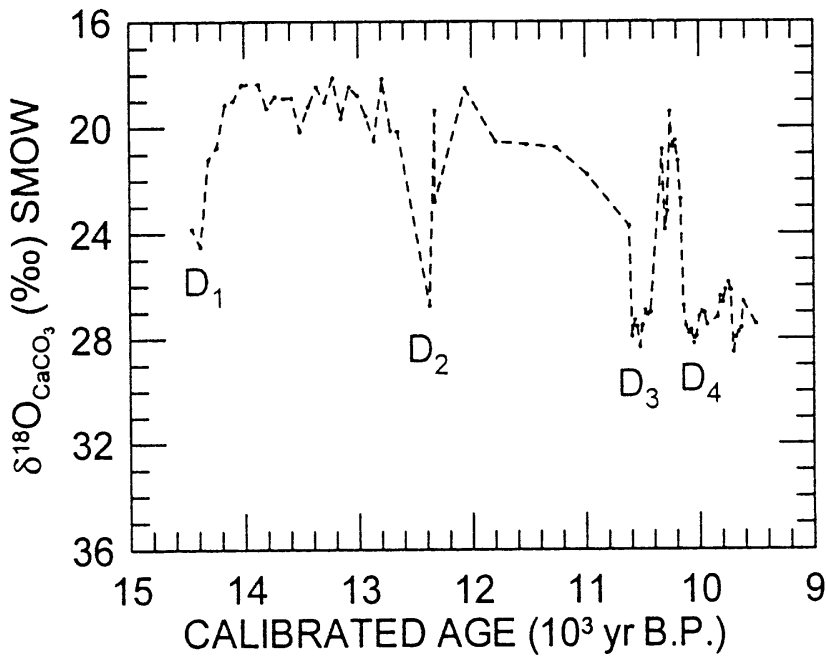

Fig. 9. $\delta^{18} \mathrm{O}_{\mathrm{CaCO}_{3}}$ record for Owens Lake between 15 and $10 \mathrm{cal}$ ka BP $\mathrm{D}_{1}, \mathrm{D}_{2}, \mathrm{D}_{3}$, and $\mathrm{D}_{4}$ signify times of climatic drying.

spill, lessening the effect of evaporation on the ${ }^{18} \mathrm{O} /{ }^{16} \mathrm{O}$ ratio of the spilling lake.

Two additional sets of simulations were run to demonstrate the effect on $\delta^{18} \mathrm{O}_{\mathrm{CaCO}_{3}}$ of a return of Owens Lake to hydrologic closure associated with either 
Table 2

Input data and results of simulations of Owens Lake $\delta^{18} \mathrm{O}$ response to abrupt changes in its hydrologic balance ${ }^{\mathrm{a}}$

\begin{tabular}{|c|c|c|c|c|c|c|c|c|}
\hline$d_{\mathrm{i}}(\mathrm{m})$ & $\delta^{18} \mathrm{O}_{\mathrm{i}}(\%)$ & $D\left(\mathrm{~km}^{3} \mathrm{yr}^{-1}\right)$ & $\delta^{18} \mathrm{O}_{\mathrm{OR}}(\%)$ & $P_{\mathrm{ol}}(\mathrm{m})$ & $\delta^{18} \mathrm{O}_{\mathrm{ol}}(\%)$ & $E(\mathrm{~m})$ & $\delta^{18} \mathrm{O}_{\text {trans }}(\%)$ & $\delta^{18} \mathrm{O}_{\mathrm{SS}, \mathrm{CC}}(\%)$ \\
\hline \multicolumn{9}{|c|}{ Cold and wet simulations (stadial mode, adjusted Pyramid Lake data used) } \\
\hline 10 & 0.0 & 0.56 & -17 & 0.30 & -17 & 0.75 & -10.4 & 26.5 \\
\hline 10 & 0.0 & 0.84 & -17 & 0.30 & -17 & 0.75 & -11.7 & 25.2 \\
\hline 10 & 0.0 & 1.69 & -17 & 0.30 & -17 & 0.75 & -13.5 & 22.1 \\
\hline \multicolumn{9}{|c|}{ Warm and dry simulations (historic mode, Pyramid Lake historical data used) } \\
\hline 65 & -5.5 & 0.36 & -15 & 0.10 & -15 & 1.50 & 8.3 & 28.9 \\
\hline 65 & -6.8 & 0.36 & -15 & 0.10 & -15 & 1.50 & 9.4 & 28.9 \\
\hline 65 & -9.9 & 0.36 & -15 & 0.10 & -15 & 1.50 & 11.9 & 28.9 \\
\hline \multicolumn{9}{|c|}{ Cold and dry Simulations (interstadial mode, adjusted Pyramid Lake data used) } \\
\hline 65 & -5.5 & 0.17 & -17 & 0.30 & -17 & 0.75 & 9.1 & $<29.5^{\mathrm{b}}$ \\
\hline 65 & -6.8 & 0.17 & -17 & 0.30 & -17 & 0.75 & 10.2 & $<29.5^{\mathrm{b}}$ \\
\hline 65 & -9.9 & 0.17 & -17 & 0.30 & -17 & 0.75 & 12.8 & $<29.5^{\mathrm{b}}$ \\
\hline
\end{tabular}

${ }^{\mathrm{a}} d_{\mathrm{i}}$, initial lake depth; $\delta^{18} \mathrm{O}_{\mathrm{i}}$, initial lake $\delta^{18} \mathrm{O} ; D$, Owens River discharge; $\delta^{18} \mathrm{O}_{\mathrm{OR}}$, Owens River $\delta^{18} \mathrm{O} ; P_{\mathrm{ol}}$, on-lake precipitation; $\delta^{18} \mathrm{O}_{\mathrm{ol}}$, on-lake precipitation $\delta^{18} \mathrm{O}$; $E$, evaporation; $\delta^{18} \mathrm{O}_{\text {trans, }}$, initial transient in $\delta^{18} \mathrm{O} ; \delta^{18} \mathrm{O}_{\mathrm{SS}, \mathrm{CC}}$, steady state value of Owens Lake calcium carbonate $\delta^{18} \mathrm{O}$.

${ }^{\mathrm{b}}$ Not run to final steady state.
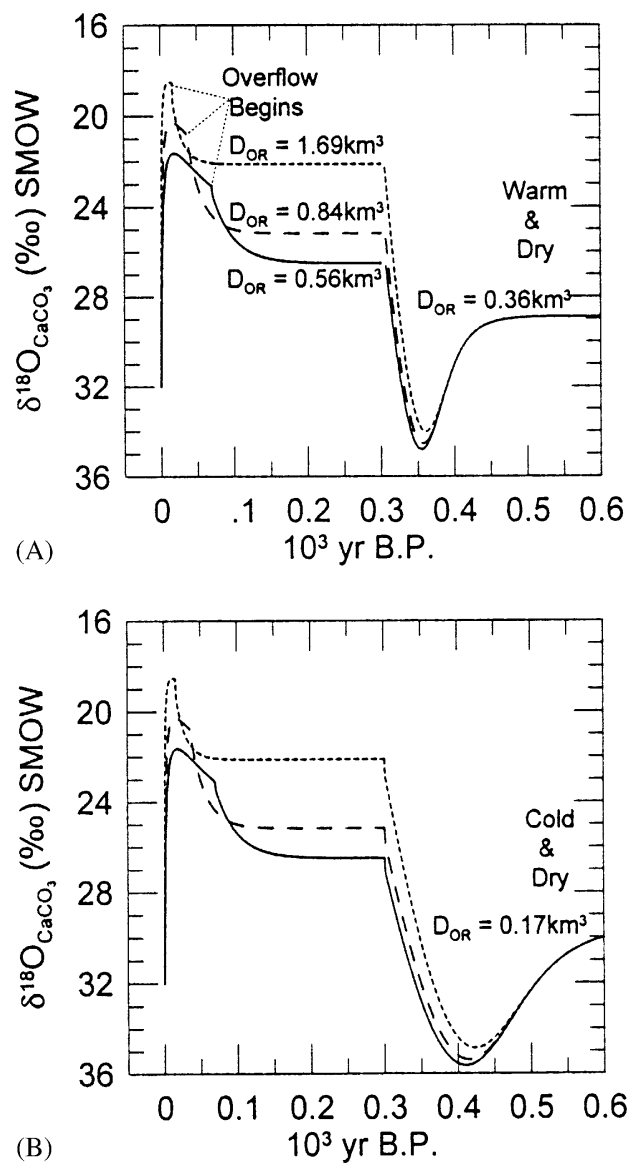

Fig. 10. Simulations of changes in $\delta^{18} \mathrm{O}_{\mathrm{CaCO}_{3}}$ resulting from overflow and hydrologic closure of Owens Lake California. The results of three sets of simulations are indicated. The first set of results show the response of $\delta^{18} \mathrm{O}_{\mathrm{CaCO}_{3}}$ precipitated from a shallow $(10 \mathrm{~m})$ closed lake to step-function increases in the hydrologic balance during the first $300 \mathrm{yr}$ of the simulations. The second and third set of results indicate how hydrologic closure during the next $300 \mathrm{yr}$ of the simulations affects $\delta^{18} \mathrm{O}_{\mathrm{CaCO}_{3}}$ during the transition from a cold-wet climate to either a warm-dry climate (A) or a cold-dry climate (B). a warm-dry or a cold-dry climate. Both sets of simulations were initialized using steady-state $\delta^{18} \mathrm{O}_{\text {lake }}$ values resulting from the three overflow simulations. Initial lake depth was set to its overflow value of $65 \mathrm{~m}$. The warm-dry simulations are meant to approximate modern-day drought conditions and the cold-dry simulations are meant to approximate drought conditions that are possibly more typical of the glacialinterglacial transition.

For the warm-dry simulations, Owens River discharge was set to a value $\left(0.36 \mathrm{~km}^{3}\right)$ that would allow the lake to achieve a steady-state depth of $\sim 10 \mathrm{~m}$. $\delta^{18} \mathrm{O}$ values of river discharge and on-lake precipitation were set to their historic values $(-15 \%$, Benson, 1999, p. 212).

For the cold-dry simulations, the model was run in its stadial mode with evaporation set to $0.75 \mathrm{~m} \mathrm{yr}^{-1}$ and precipitation set to its historical value of $0.10 \mathrm{~m} \mathrm{yr}^{-1}$. Owens River discharge was set to a value $\left(0.17 \mathrm{~km}^{3}\right)$ that would allow the lake to achieve a steady-state depth of $\sim 10 \mathrm{~m}$. $\delta^{18} \mathrm{O}$ values of river discharge and onlake precipitation were set to their stadial values $(-17 \%)$.

Results of both sets of the warm-dry and cold-dry simulations (Table 2, Fig. 10A, B, 300-600 yr) indicate an abrupt transient increase in $\delta^{18} \mathrm{O}_{\mathrm{CaCO}_{3}}$ of 8.3 to $12.8 \%$ followed by a 150 - to 300 -yr exponential decay to steady-state $\delta^{18} \mathrm{O}$ values of $28.9 \%$ (Fig. 10A) and $<29.5 \%$ (Fig. 10B). During the dry intervals, $\delta^{18} \mathrm{O}_{\text {lake }}$ increases as the lake shrinks, reflecting the dominance of evaporation on the hydrologic and isotopic balances. Simulations of the response of Owens Lake $\boldsymbol{\delta}^{18} \mathrm{O}_{\mathrm{CaCO}_{3}}$ to overflow and hydrologic closure yield $\delta^{18} \mathrm{O}_{\mathrm{CaCO}_{3}}$ excursions of similar magnitude and duration to those observed in the actual Owens Lake $\delta^{18} \mathrm{O}$ record between 15 and $10 \mathrm{cal} \mathrm{ka} \mathrm{BP} \mathrm{(Fig.} 9$ and 10), supporting the concept that the abrupt oscillations in $\delta^{18} \mathrm{O}$ resulted 
from step-function changes in the hydrologic balance. We have therefore shown that HIBAL can be used to simulate "interesting" parts of a paleolake $\delta^{18} \mathrm{O}$ record.

\section{Discussion}

We have presented a simple hydrologic-isotopicbalance model for application to lake and paleolake $\delta^{18} \mathrm{O}$ records and have demonstrated the ability of the model to simulate changes in the hydrologic balance and the $\delta^{18} \mathrm{O}$ evolution of the lake, using measured data from Pyramid Lake and Walker Lake, Nevada, and Owens Lake, California. Simulations of the response in $\delta^{18} \mathrm{O}$ to step- and periodic-function changes in the hydrologic balance indicate that $\delta^{18} \mathrm{O}$ tends to lag climate change on time scales similar to that which volume lags climate change. The $\delta^{18} \mathrm{O}$ response to a step-function perturbation in the hydrologic balance consists of an initial transient that lasts several decades. Because climate varies on all time scales, the hydrologic balance always changes before the steady-state $\delta^{18} \mathrm{O}$ value is achieved and usually prior to the end of the transient response. This implies that the lacustrine $\delta^{18} \mathrm{O}$ record is composed of a sequence of initial transient responses to high- and middle-frequency climate perturbations that are superimposed on a low-frequency background of climate change. Neither lake volume nor $\delta^{18} \mathrm{O}$ ever reach equilibrium with climate forcing which can be envisioned as occurring as a series of stepfunctions. Even though the $\delta^{18} \mathrm{O}$ response lags climate forcing, the initial phase of the transient always reflects the immediate hydrologic response; i.e., when volume increases, $\delta^{18} \mathrm{O}$ decreases and vice versa. Thus, the derivative of $\delta^{18} \mathrm{O}$ will yield the direction of climate change; i.e., whether climate is becoming drier or wetter (Benson et al., 2001). Because the shape (amplitude) of the $\delta^{18} \mathrm{O}$ transient is dependent on lake size at the time of the hydrologic perturbation, it cannot be used to assess how wet or how dry the climate was unless the initial lake level is known. We have, however, illustrated that the $\delta^{18} \mathrm{O}$ response of a hydrologically closed lake does tend to mimic its volume change.

\section{Acknowledgements}

The authors thank Steve Hostetler of the US Geological Survey and John Andrews of the University of Colorado for their reviews of this paper.

\section{Appendix A. The HIBAL model and its inputs}

This appendix contains governing equations used in the isotopic mass-balance of a lake, a description of the
HIBAL model, a discussion of its application to Pyramid Lake, a description of the behavior of $\delta^{18} \mathrm{O}$ in the Truckee River-Pyramid Lake system, and a discussion of the data used as inputs to the HIBAL model. Inputs to simulations of the Walker Lake and Owens Lake systems are discussed in the text. HIBAL is written in FORTRAN; a hard copy of the Pyramid Lake version together with input files is available from the senior author (lbenson@usgs.gov).

\section{A.1. Governing equations}

The isotopic mass balance of a lake is given by

$$
\begin{aligned}
\frac{\partial(\delta V)}{\partial t}= & \left(P \delta_{\mathrm{P}}-E \delta_{\mathrm{evap}}\right) A+V_{\mathrm{D}, \mathrm{i}} \delta D_{\mathrm{i}}-V_{\mathrm{D}, \mathrm{o}} \delta D_{\mathrm{o}} \\
& +V_{\mathrm{G}, \mathrm{i}} \delta G_{\mathrm{i}}-V_{\mathrm{G}, \mathrm{o}} \delta G_{\mathrm{o}}
\end{aligned}
$$

where $t$ is time, $V$ is lake volume, $P$ is the amount of onlake precipitation, $\delta_{\mathrm{P}}$ is the $\delta^{18} \mathrm{O}$ value of precipitation, $E$ is the amount of evaporation, $\delta_{\text {evap }}$ is the $\delta^{18} \mathrm{O}$ value of water vapor leaving the lake surface, $A$ is the surface area of the lake, $V_{\mathrm{D}, \mathrm{i}}$ is the discharge volume, $\delta D_{\mathrm{i}}$ is the $\delta^{18} \mathrm{O}$ value of discharge, $V_{\mathrm{D}, \mathrm{o}}$ is the volume of surface water lost from the lake as overflow, $\delta D_{\mathrm{o}}$ is the $\delta^{18} \mathrm{O}$ value of overflow, $V_{\mathrm{G}, \mathrm{i}}$ is the volume of ground water input to the lake, $\delta G_{\mathrm{i}}$ is the $\delta^{18} \mathrm{O}$ value of ground-water discharge, $V_{\mathrm{G}, \mathrm{o}}$ is the volume of ground-water output from the lake, and $\delta G_{\mathrm{o}}$ is the $\delta^{18} \mathrm{O}$ value of the output ground water (Gonfiantini, 1965).

For a closed-basin lake in which in which groundwater flux is negligible and surface overflow does not occur, Eq. (A.1) reduces to

$\frac{\partial(\delta V)}{\partial t}=\left(P \delta_{\mathrm{P}}-E \delta_{\mathrm{evap}}\right) A+V_{\mathrm{D}, \mathrm{i}} \delta D_{\mathrm{i}}$.

Benson and White (1994) derived an expression for $\delta_{\text {evap }}$ based on the conceptual model of Craig and Gordon (1965), deviating from their seminal derivation in four ways:

1. The derivation of the basic set of equations that describe isotopic fraction was done in terms of ratios of isotopic species, $R_{\mathrm{i}}$, allowing conversion of laboratory values of $\delta_{\mathrm{i}}$ to $\mathbf{R}_{\mathrm{i}}$, using

$\delta_{\mathrm{i}}=\left(\mathbf{R}_{\mathrm{i}}-1\right) 10^{3}$,

where bold-type $\mathbf{R}_{\mathrm{i}}$ is the ${ }^{18} \mathrm{O}:{ }^{16} \mathrm{O}$ ratio of a sample $\left(R_{\mathrm{i}}\right)$ divided by the corresponding isotopic ratio of a standard $\left(R_{\text {std }}\right)$.

2. The derivation includes an expression for the ${ }^{18} \mathrm{O}:{ }^{16} \mathrm{O}$ ratio of evaporating moisture $\left(\mathbf{R}_{\text {evap }}\right)$ in terms of the fractions of advected and lake-derived moisture.

3. The equilibrium and kinetic fractionation of ${ }^{18} \mathrm{O}$ and ${ }^{16} \mathrm{O}$ are separately treated in the derivation, allowing the use of Merlivat and Jouzel's (1979) determina- 
tions of the dependence of the kinetic fractionation factor on wind speed.

4. Benson and White (1994) also derived an expression for the net vapor flux that avoids introduction of gross evaporation and back-condensation fluxes, quantities that are nearly impossible to measure.

According to Benson and White (1994), the ${ }^{18} \mathrm{O}:{ }^{16} \mathrm{O}$ ratio in water vapor released from the lake surface during evaporation ( $\mathbf{R}_{\text {evap }}$ ) is given by

$\mathbf{R}_{\text {evap }}=\frac{\mathbf{R}_{\text {lake }} / \alpha_{\text {eq }}-\mathrm{RH} f_{\text {ad }} \mathbf{R}_{\text {ad }}}{\left(1-\mathrm{RH} / \alpha_{\text {kin }}\right)+\operatorname{RH}\left(1-f_{\text {ad }}\right)}$,

where $\mathbf{R}_{\text {lake }}$ and $\mathbf{R}_{\text {ad }}$ are the ${ }^{18} \mathrm{O}:{ }^{16} \mathrm{O}$ ratios in lake water and advected water vapor, $f_{\text {ad }}$ is the fraction of advected water vapor in the boundary layer over the lake, $\mathrm{RH}$ is the relative humidity of the boundary layer, and $\alpha_{\mathrm{eq}}$ and $\alpha_{\text {kin }}$ are the equilibrium and kinetic fractionation factors.

If all the water vapor overlying the lake is derived by evaporation, $f_{\text {ad }}=0$ and Eq. (A.4) becomes

$\mathbf{R}_{\text {evap }}=\mathbf{R}_{\text {lake }} \frac{\alpha_{\text {kin }}}{\alpha_{\text {eq }}}\left(\frac{1}{1-\mathrm{RH}+\mathrm{RH} \alpha_{\mathrm{kin}}}\right)$.

Isotope ratios can be converted to del $(\delta)$ values using Eq. (A.3) and values of the equilibrium fractionation factor, $\alpha_{\text {eq }}$, can be calculated from

$\alpha_{\text {eq }}=\exp \left(1137 T_{\text {lake }}^{-2}-0.4156 T_{\text {lake }}^{-1}-2.0667 \times 10^{-3}\right)$

where the temperature of lake surface water, $T_{\text {lake }}$, is in $\mathrm{K}$ (Majoube, 1971). For wind speeds $<6.8 \mathrm{~m} \mathrm{~s}^{-1}, \alpha_{\mathrm{kin}}=$ 0.994 and for wind speeds between 6.8 and $12.5 \mathrm{~m} \mathrm{~s}^{-1}$, values of $\alpha_{\text {kin }}$ range from 0.9955 to 0.9975 (Merlivat and Jouzel, 1979).

If we define the fractionation of $\delta^{18} \mathrm{O}$ during evaporation as the difference between $\delta^{18} \mathrm{O}$ in the water vapor and the $\delta^{18} \mathrm{O}$ in evaporating lake water $\left(\delta^{18} \mathrm{O}_{\text {evap }}-\delta^{18} \mathrm{O}_{\text {lake }}\right), \quad \delta^{18} \mathrm{O}$ fractionation can be displayed as a function of $f_{\text {ad }}, \mathrm{RH}, \delta^{18} \mathrm{O}_{\text {ad }}$, and $T_{\text {lake }}$ using Eqs. (A.3) and (A.4). When $f_{\text {ad }}=0$, the fractionation of $\delta^{18} \mathrm{O}$ decreases $\sim 0.6 \%$ with a $10 \%$ increase in $\mathrm{RH}$; however, with an increase in $f_{\text {ad }}$, the fractionation of $\delta^{18} \mathrm{O}$ becomes increasingly sensitive to the value of $\delta^{18} \mathrm{O}_{\text {ad }}$, e.g., when $f_{\text {ad }}=0.2, \quad \delta^{18} \mathrm{O}_{\text {evap }}-\delta^{18} \mathrm{O}_{\text {lake }}$ decreases $0.5 \%$ with every $3 \%$ decrease in $\delta^{18} \mathrm{O}_{\mathrm{ad}}$ (Fig. 11A). Fractionation of $\delta^{18} \mathrm{O}$ during evaporation decreases $\sim 0.09 \%$ with each $1 \mathrm{~K}$ increase in $T_{\text {lake }}$ (Fig. 11B).

\section{A.2. Model description and its application to Pyramid Lake}

HIBAL is a two-box "forward" model that runs on a monthly time step. For inputs, the model requires fluid fluxes, their associated $\delta^{18} \mathrm{O}$ values, depth of the mixed layer, basin hypsometry, and a set of meteorological data that govern the fractionation of $\delta^{18} \mathrm{O}$ during evaporation and precipitation of $\mathrm{CaCO}_{3}$.

Monthly values of normalized on-lake precipitation $(\hat{P})$, mixed-layer depth $\left(d_{\mathrm{ml}}\right)$, lake-surface temperature $\left(T_{\text {lake }}\right)$, relative humidity $(\mathrm{RH})$, normalized discharge $(\hat{D})$, normalized evaporation $(\hat{E})$, and the polynomials that relate volume $(V)$ and surface area $(A)$ to lake depth $(d)$ are read from within HIBAL. There are two external input files. The "flow" file contains a list of annual discharges. The "parameter file" includes values of annual evaporation $(E)$ and on-lake precipitation $(P)$, initial lake depth $\left(d_{\mathrm{i}}\right)$, the fraction of advected moisture $\left(f_{\text {ad }}\right)$ in the boundary layer over the lake, the fraction of inflow from Lake Tahoe (0.333), the value of Truckee River discharge (at the Farad gage) at which Lake Tahoe ceases to overflow $\left(0.28 \mathrm{~km}^{3}\right)$, and $\delta^{18} \mathrm{O}$ values for
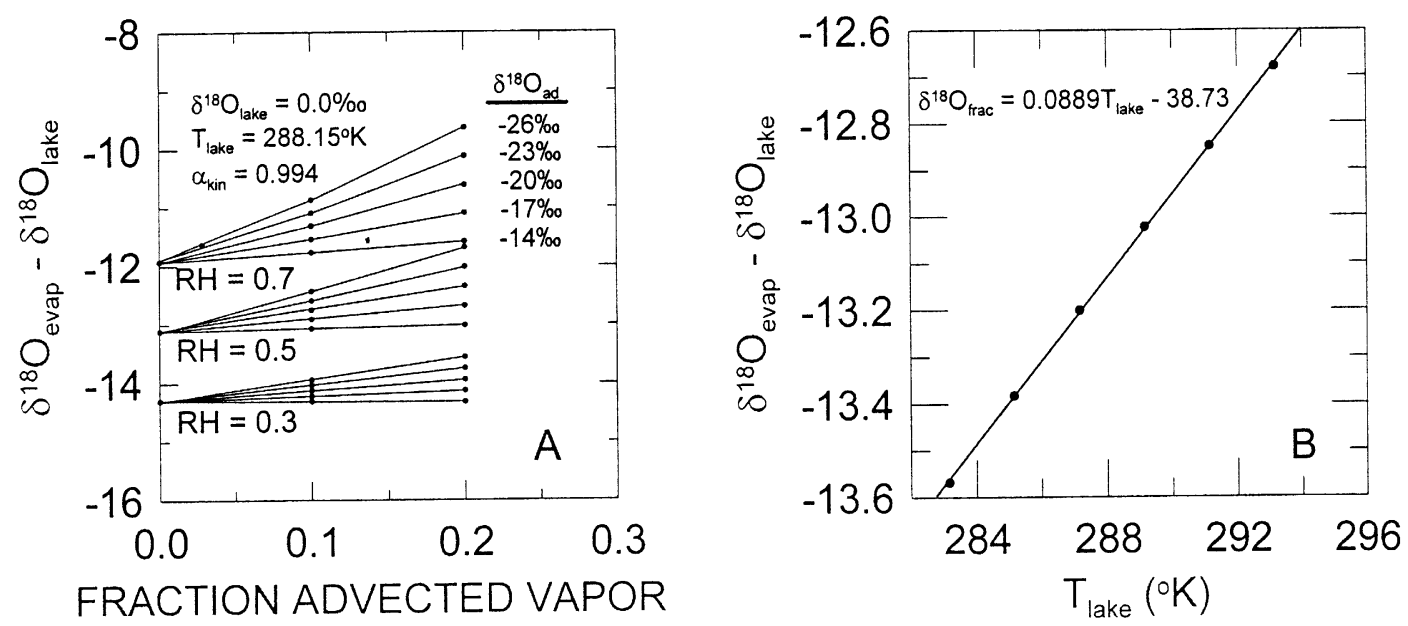

Fig. 11. (A) The evaporation fractionation factor $\left(\delta^{18} \mathrm{O}_{\text {evap }}-\delta^{18} \mathrm{O}_{\text {lake }}\right)$ as a function of the fraction of advected vapor $\left(f_{\text {ad }}\right)$, relative humidity, $(\mathrm{RH})$, and the $\delta^{18} \mathrm{O}$ value of advected vapor $\left(\delta^{18} \mathrm{O}_{\mathrm{ad}}\right)$. (B) The evaporation fractionation factor $\left(\delta^{18} \mathrm{O}_{\text {evap }}-\delta^{18} \mathrm{O}_{\text {lake }}\right)$ as a function of surface-water temperature $\left(T_{\text {lake }}\right)$. 
the following: Pyramid Lake water, snowmelt, on-lake precipitation, advected moisture, and Lake Tahoe outflow.

After the inputs are read, the program performs the following sequence of calculations: For the first month,

1. Initial lake volume and surface area are calculated from the initial depth.

2. Fractionation factors $\left(\alpha_{\mathrm{kin}}, \alpha_{\mathrm{eq}}, \alpha_{\mathrm{H}_{2} \mathrm{O}-\mathrm{CaCO}_{3}}\right)$ are read in or computed.

3. Discharge and on-lake precipitation are added to the lake.

4. Volume-weighted $\delta^{18} \mathrm{O}$ values of discharge and precipitation are combined with the volume-weighted $\delta^{18} \mathrm{O}$ value of the mixed layer.

5. The new volume is compared with the overflow volume. If the new volume is greater than the overflow volume, the excess volume is subtracted; i.e., the overflow is routed to the adjacent Winnemucca Lake basin

6. Evaporation is subtracted from the lake.

7. The volume-weighted $\delta^{18} \mathrm{O}$ value of the vapor phase $\left(\delta^{18} \mathrm{O}_{\text {evap }}\right)$ is calculated and then subtracted from the volume-weighted $\delta^{18} \mathrm{O}$ value of the mixed layer.

8. The base of the mixed layer is moved to the next month's depth, and if the base penetrates the hypolimnion volume, the volume-weighted $\delta^{18} \mathrm{O}$ value of the entrained hypolimnion volume is mixed with the volume-weighted $\delta^{18} \mathrm{O}$ value of the mixed layer.

Output consists of a listing of input variable values $D$, $d$, and $V$ for each model year together with monthly values of $\delta^{18} \mathrm{O}_{\text {lake }}$ and $\delta^{18} \mathrm{O}_{\mathrm{CaCO}_{3}}$. The model was also tested with evaporation being subtracted before the excess volume was subtracted, using measured Nixon discharge values from 1916 through 1996. Simulated lake level and $\delta^{18} \mathrm{O}$ records were identical in both simulations.

\section{A.3. The behavior of $\delta^{18} O$ in the Truckee River-Pyramid Lake surface-water system}

The study by Benson (1994) provides the basis for our understanding of the behavior of $\delta^{18} \mathrm{O}$ in the Truckee
River-Pyramid Lake surface-water system. In that study, the weighted average $\delta^{18} \mathrm{O}$ of precipitation at Tahoe Meadows (Fig. 2) was found to be identical to the $-14.6 \%$ value of shallow ground water in the Lake Tahoe area (Table 3). The $-14.6 \%$ value represents the isotopic composition of overland flow and shallow ground water that discharge to the Truckee River at its headwaters. The $\delta^{18} \mathrm{O}$ value of the Truckee River at the Farad site, however, is heavier, oscillating between extremes of $\sim-7 \%$ and $-13 \%$ over the annual cycle (Fig. 12), due to the mixing of Lake Tahoe overflow $\left(\delta^{18} \mathrm{O}=-5.6 \%\right.$ ) (Fig. 2, Table 3) with $-14.6 \%$ water derived from snowmelt (Fig. 13). The fraction of Tahoederived water entering the Truckee River system is not constant, but tends to increase sharply between July and September (Fig. 14).

During wet years, the $\delta^{18} \mathrm{O}$ value of Pyramid Lake's epilimnion (mixed layer) decreases in response to the large volume of isotopically light Truckee River water that flows into the lake (Fig. 15). Throughout the evaporation season, the lake warms and the mixed layer deepens (Fig. 16), and the $\delta^{18} \mathrm{O}$ value of the mixed layer increases in response to the preferential loss of ${ }^{16} \mathrm{O}$ to the atmosphere (Fig. 15). In January, the lake becomes

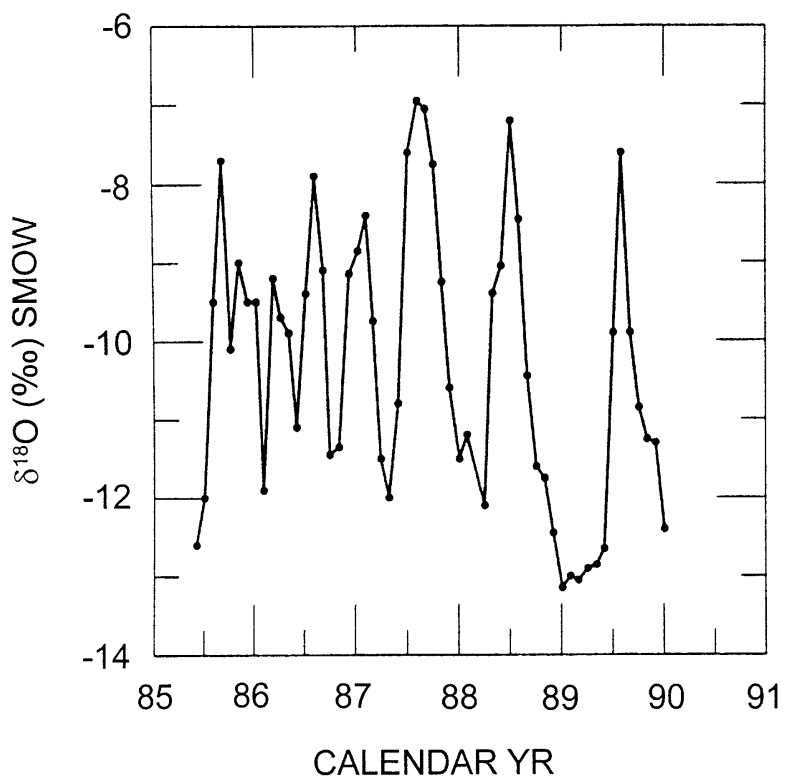

Fig. 12. The $\delta^{18} \mathrm{O}$ values of water from the Farad site.

Table 3

Oxygen-18 values for precipitation, ground-water, and river water samples from the Pyramid Lake drainage basin

\begin{tabular}{llccc}
\hline Sampling site & Sample type & Ave $\delta^{18} \mathrm{O}$ & Wt Ave $\delta^{18} \mathrm{O}$ & No. samples \\
\hline Tahoe meadows & Precipitation & -14.2 & -14.6 & 134 \\
Sutcliffe & Precipitation & -9.8 & -10.6 & NA \\
Lake Tahoe area wells & Ground water & -14.6 & -5.6 & 8 \\
Truckee River, Tahoe City & River water & -5.6 & -10.1 & 30 \\
Truckee River, Farad & River water & -10.3 & -9.9 & 55 \\
Truckee River, Nixon & River water & -10.4 & 61 \\
\hline
\end{tabular}




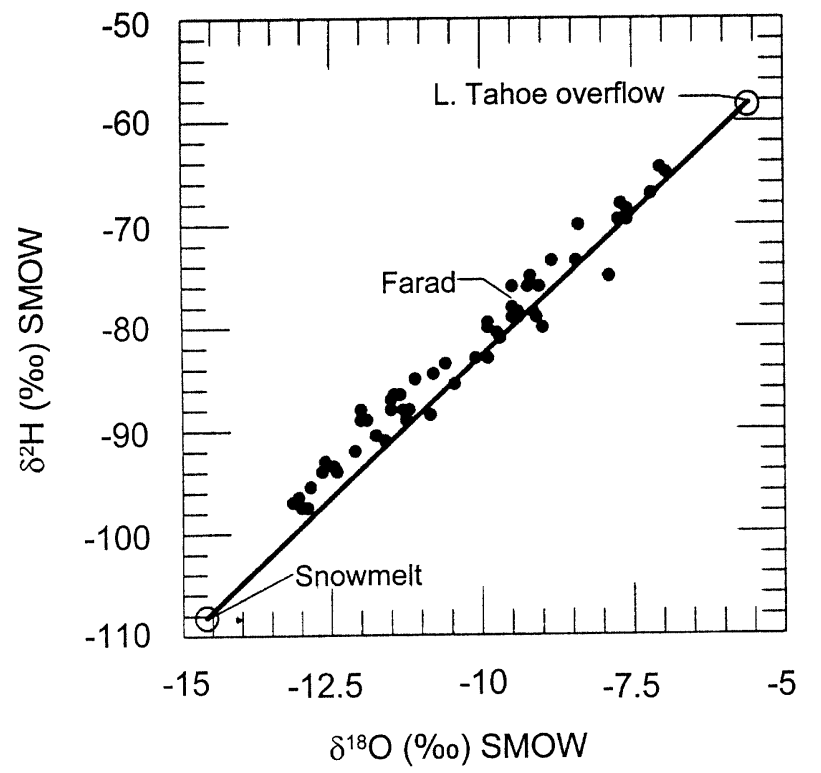

Fig. 13. Farad $\delta^{18} \mathrm{O}$ and $\delta^{2} \mathrm{H}$ values plotted on a mixing diagram. The solid line indicates values of the two isotopes that would result from mixing of Lake Tahoe overflow with snowmelt.

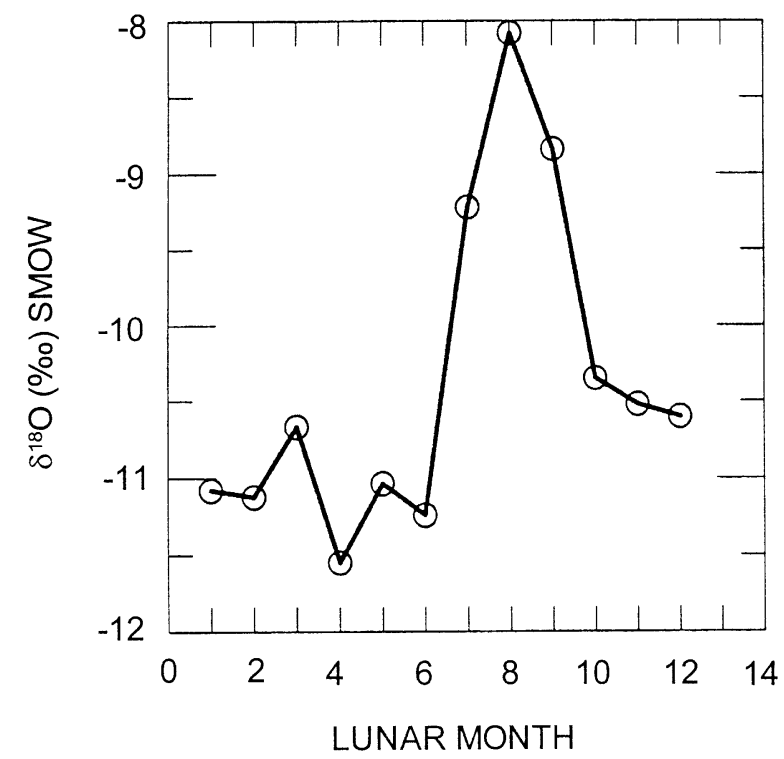

Fig. 14. The $\delta^{18} \mathrm{O}$ values of water at the Farad site plotted as a function of lunar month. The data indicate that most of the water passing the Farad site in the late autumn is derived from Lake Tahoe overflow.

isothermal and fully mixes (Fig. 16), homogenizing the epilimnion and hypolimnion $\delta^{18} \mathrm{O}$ values (Fig. 15).

With regard to the use of $\delta^{18} \mathrm{O}$ values in historical simulations of the evolution of Pyramid Lake $\delta^{18} \mathrm{O}$, the observed seasonal distribution of Truckee River $\delta^{18} \mathrm{O}$ (Fig. 14) was ignored and it was assumed that when Lake Tahoe overflowed, it contributed one-third of the total Truckee River discharge to Pyramid Lake. Thus, discharge was given a $\delta^{18} \mathrm{O}$ value of $-11.6 \%$. The

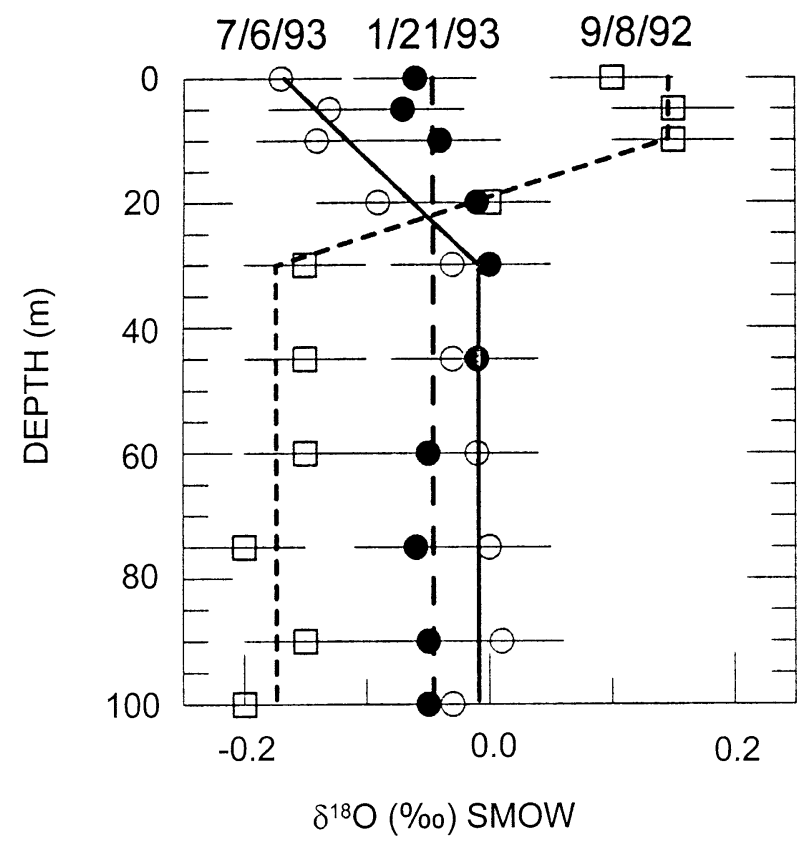

Fig. 15. Profiles of $\delta^{18} \mathrm{O}$ from Pyramid Lake taken during early summer (7/6/93), autumn (9/8/92), and late winter (1/21/93). Note that the lake becomes isothermal in January, fully mixing and homogenizing its isotopic composition.

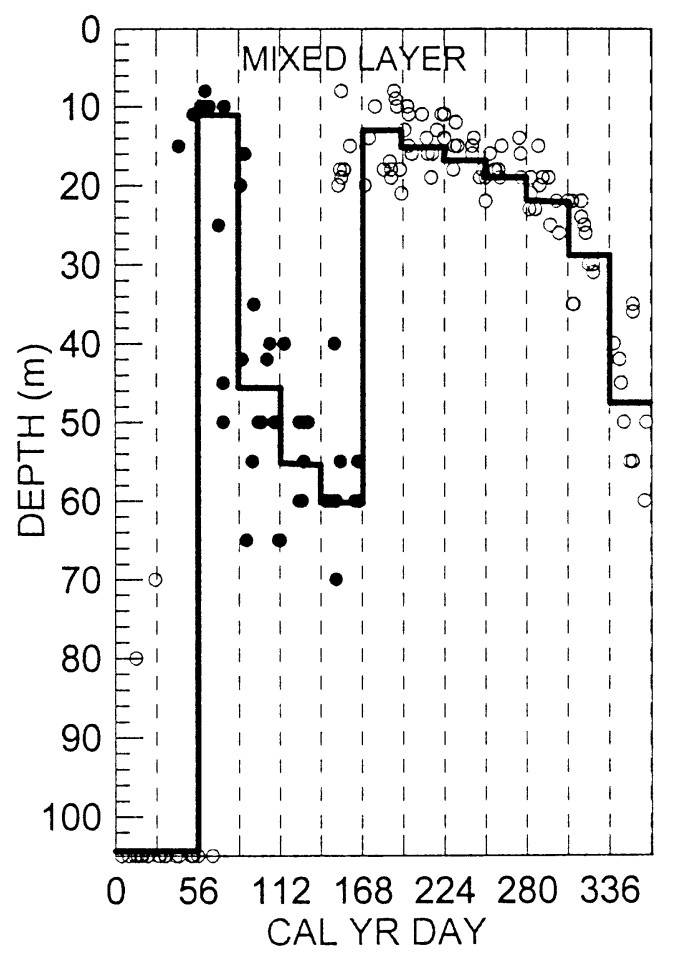

Fig. 16. Depth of the mixed layer in Pyramid Lake over the annual cycle. Solid dots indicate base of a somewhat unstable mixed layer. Open circles indicate the base of a stable mixed layer. Data were provided by the Pyramid Lake Paiute Resources Group.

$\delta^{18} \mathrm{O}$ value of on-lake precipitation was set to the weighted-mean value measured at Sutcliffe $(-10.6 \%$ o (Table 3). 

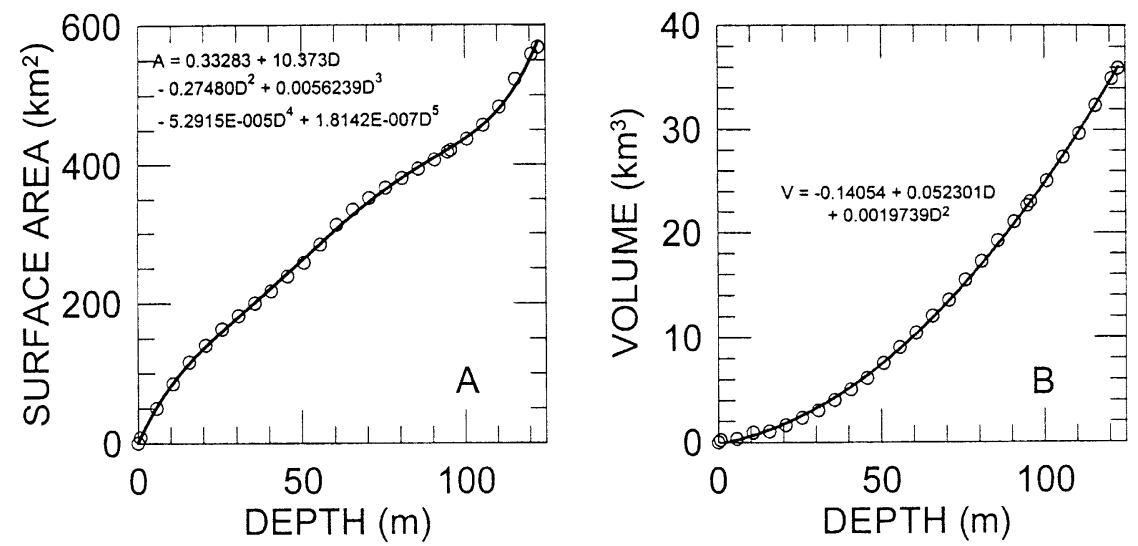

Fig. 17. Plots of Pyramid Lake hypsometric data (Benson and Mifflin, 1986). (A) Surface area vs. depth. (B) Volume vs. depth.

Table 4

Precipitation data from selected weather stations located in the Pyramid Lake drainage basin

\begin{tabular}{lll}
\hline Weather station & Record length $(\mathrm{yr})$ & Annual precip. $(\mathrm{m})$ \\
\hline Tahoe meadows & 23 & $1.31 \pm 0.52$ \\
Reno airport & 54 & $0.18 \pm 0.06$ \\
Sutcliffe & 20 & $0.21 \pm 0.08$ \\
Nixon & 40 & $0.16 \pm 0.07$ \\
Wadsworth & 17 & $0.17 \pm 0.08$ \\
\hline
\end{tabular}

\section{A.4. Model inputs}

Monthly mixed-layer depths were fit to data taken on a more-or-less monthly basis between October 1985 and January 1999 (Fig. 16). The lake undergoes complete mixing throughout the first two lunar months. Polynomials were fit to available surface area-depth and volume-depth data (Benson and Mifflin, 1986) for the Pyramid Lake basin (Fig. 17A,B). Hydrologic and meteorological input data sets were tabulated for lunar months of the calendar year. The choice of lunar month is arbitrary but dispenses with the necessity of "weighting" Julian-month data given their unequal lengths.

Monthly values of on-lake precipitation were calculated using data from four weather stations located at Sutcliffe, Nixon, Wadsworth, and Reno, Nevada (Fig. 2). These stations are in low-elevation basins located east of the Sierra Nevada and they exhibit annual values of precipitation that are statistically indistinguishable (Table 4). Correlation of annual values of near-lake precipitation with Reno precipitation is satisfactory, suggesting that data from any one of the four stations can be used when only from only one station is available (Fig. 18). Mean-annual historical values of on-lake precipitation were estimated using, in order of preference, monthly data from Sutcliffe, Nixon,

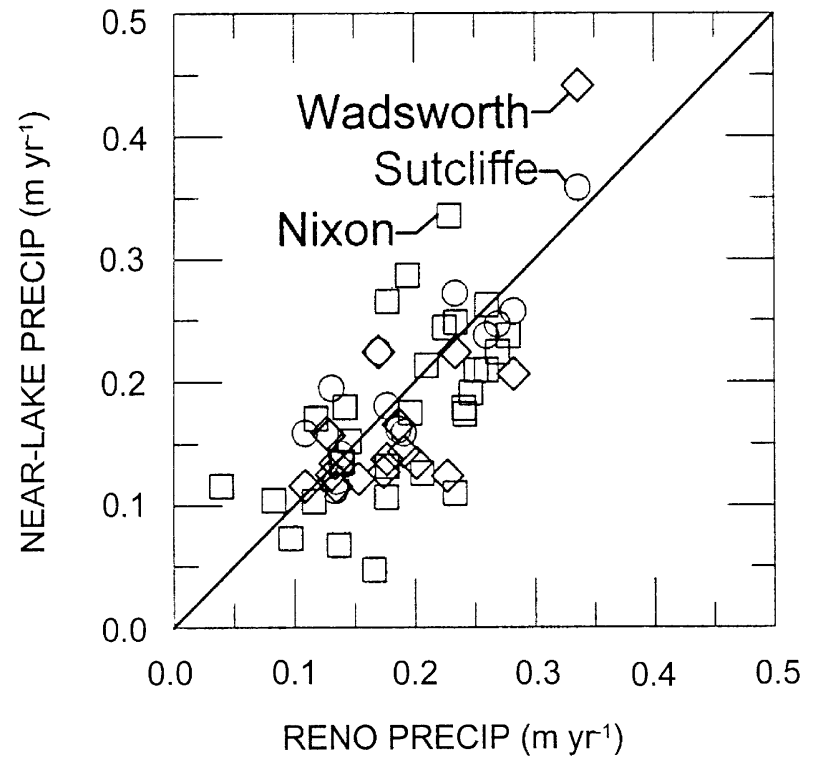

Fig. 18. Precipitation from weather stations near Pyramid Lake compared to Reno, Nevada, precipitation. Data were obtained from the Western Climate Data Center, Desert Research Institute, Reno, Nevada.

Wadsworth and Reno (Fig. 19). The mean-value of precipitation obtained in this manner is statistically indistinguishable from the non-weighted annual mean of all four weather stations (Table 4). The monthly distribution of precipitation was calculated by averaging monthly values of the station nearest Pyramid Lake (Sutcliffe) with the site having the longest record (Reno) (Table 5) and the monthly distribution was then normalized (Table 6).

The annual evaporation rate was calculated by two methods. Calendar-year discharge and precipitation values, together with lake-level data (converted to volume and surface area) for the period 1932-1996, were used to calculate a hydrologic-balance evaporation 
rate of $1.21 \pm 0.16 \mathrm{~m} \mathrm{yr}^{-1}$. We also fit an optimized annual-evaporation rate using calendar-year discharge, precipitation, and measured lake level for the period 1938-1996, obtaining a value of $1.18 \mathrm{~m} \mathrm{yr}^{-1}$ (Fig. 20). The optimization was based on the minimization of the root-mean-square difference between measured and computed water levels over the period of record.

Long-term pan-evaporation data suggest that a single value of evaporation can be used from year to year. The uncorrected value of $\mathrm{E}$ measured at Fallon, Nevada

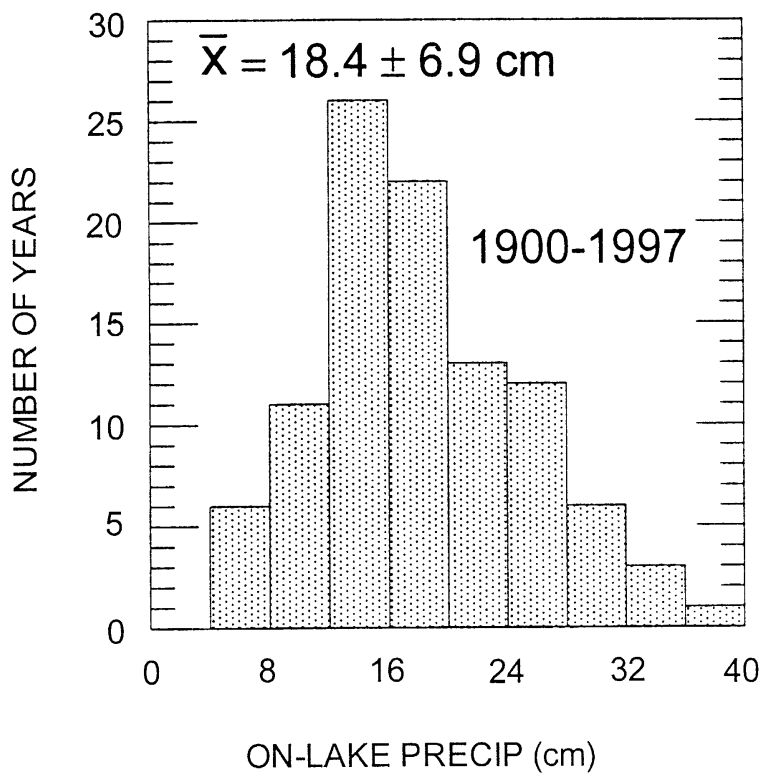

Fig. 19. Histogram of annual precipitation in the Pyramid Lake area (1900-1997). A single year's data came from a single site. When data for multiple sites were available, data were taken from the site closest to the lake. using a class A pan was $0.89 \pm 0.08 \mathrm{~m} \mathrm{yr}^{-1}$ for the period 1957 through 1992. To distribute the annual evaporation of $1.2 \mathrm{~m} \mathrm{yr}^{-1}$ over the annual cycle, monthly modeled evaporation rates calculated by Hostetler and Benson (1994)(Table 4) were normalized (Table 6) and the annual value multiplied by each of the monthly normalized values

Annual and monthly values of Truckee River discharge were obtained from the Farad and Nixon gaging stations (Fig. 2)(US Geological Survey WaterData Reports, 1916-1996). The Farad data represent an approximation of pristine Truckee River flows that would reach Pyramid Lake; i.e., most consumptive use of water occurs below the Farad site. Data from the Nixon gage indicates the amount of water that actually reaches Pyramid Lake. Before construction of the Derby Dam (1906), Farad and Nixon discharges were nearly equivalent.

Gaging at the Nixon site commenced in 1958. To extend the Nixon record to 1916, annual discharges recorded at the gaging station located below Derby Dam were correlated to Nixon discharges (Fig. 21). We elected to distribute annual Farad and Nixon discharges using the Farad distribution. We first compared the individual monthly data for both sites, noting that they were similar in form before we averaged the Farad monthly discharges (Table 5). We then checked to see that the shapes of the flow distributions were similar during high- and low-flow years (Fig. 22), prior to normalization of the Farad monthly data (Table 6). In the model, annual discharges are multiplied by monthly normalized discharge values in order to obtain monthly flows. We elected to use normalized discharges as opposed to measured-monthly discharges because measured data are not available for surface-water systems prior to 1900 .

Table 5

Lunar monthly hydrologic and climatic data for the Pyramid Lake basin ${ }^{\mathrm{a}}$

\begin{tabular}{|c|c|c|c|c|c|c|c|}
\hline $\begin{array}{l}\text { Lunar } \\
\text { month }\end{array}$ & $\begin{array}{l}\text { Farad discharge } \\
\left(\mathrm{km}^{3}\right)\end{array}$ & $\begin{array}{l}\text { On-lake } \\
\text { precip (m) }\end{array}$ & $\begin{array}{l}\text { Evaporation } \\
\text { (m) }\end{array}$ & $\begin{array}{l}\text { Water temp } \\
\left({ }^{\circ} \mathrm{C}\right)\end{array}$ & $\begin{array}{l}\text { Sutcliffe air } \\
\text { temp }\left({ }^{\circ} \mathrm{C}\right)\end{array}$ & $\begin{array}{l}\mathrm{RH} \\
(\%)\end{array}$ & $\begin{array}{l}\text { Wind speed } \\
\left(\mathrm{m} \mathrm{s}^{-1}\right)\end{array}$ \\
\hline 1 & $0.037 \pm 0.031$ & 0.0292 & 0.0436 & $6.66 \pm 0.54$ & $2.33 \pm 2.72$ & 73 & 3.17 \\
\hline 2 & $0.042 \pm 0.035$ & 0.0230 & 0.0372 & $7.08 \pm 1.24$ & $3.88 \pm 3.12$ & 68 & 2.82 \\
\hline 3 & $0.050 \pm 0.041$ & 0.0198 & 0.0462 & $7.83 \pm 2.17$ & $7.21 \pm 2.64$ & 55 & 3.52 \\
\hline 4 & $0.077 \pm 0.049$ & 0.0106 & 0.0772 & $10.05 \pm 1.92$ & $9.93 \pm 2.65$ & 47 & 3.49 \\
\hline 5 & $0.115 \pm 0.071$ & 0.0140 & 0.1045 & $13.07 \pm 3.74$ & $13.76 \pm 2.76$ & 47 & 3.87 \\
\hline 6 & $0.105 \pm 0.075$ & 0.0169 & 0.1295 & $16.41 \pm 2.84$ & $17.59 \pm 3.03$ & 46 & 4.14 \\
\hline 7 & $0.060 \pm 0.046$ & 0.0060 & 0.1693 & $20.77 \pm 2.18$ & $22.38 \pm 2.23$ & 35 & 4.09 \\
\hline 8 & $0.038 \pm 0.017$ & 0.0057 & 0.1753 & $23.15 \pm 0.93$ & $24.97 \pm 1.86$ & 37 & 3.98 \\
\hline 9 & $0.033 \pm 0.011$ & 0.0060 & 0.1636 & $22.34 \pm 1.32$ & $22.50 \pm 2.05$ & 32 & 3.67 \\
\hline 10 & $0.030 \pm 0.014$ & 0.0110 & 0.1232 & $20.00 \pm 1.68$ & $17.66 \pm 2.39$ & 41 & 3.33 \\
\hline 11 & $0.026 \pm 0.012$ & 0.0101 & 0.0910 & $16.61 \pm 1.89$ & $11.81 \pm 2.94$ & 50 & 2.83 \\
\hline 12 & $0.030 \pm 0.028$ & 0.0218 & 0.0821 & $12.62 \pm 1.45$ & $6.48 \pm 2.40$ & 64 & 3.61 \\
\hline 13 & $0.037 \pm 0.040$ & 0.0255 & 0.0727 & $9.02 \pm 0.90$ & $2.83 \pm 3.07$ & 67 & 3.90 \\
\hline
\end{tabular}

${ }^{a}$ Note: Monthly evaporation data are from a thermal simulation made by Hostetler and Benson (1994). All other data are measured values. See text for discussion. 
Table 6

Normalized lunar monthly values of discharge, on-lake precipitation and evaporation

\begin{tabular}{llll}
\hline Lunar month & $\begin{array}{l}\text { Farad discharge } \\
\text { (normalized) }\end{array}$ & $\begin{array}{l}\text { On-lake precip } \\
\text { (normalized) }\end{array}$ & $\begin{array}{l}\text { Evaporation } \\
\text { (normalized) }\end{array}$ \\
\hline 1 & 0.0543 & 0.146 & 0.033 \\
2 & 0.0625 & 0.115 & 0.028 \\
3 & 0.0731 & 0.099 & 0.035 \\
4 & 0.1127 & 0.053 & 0.059 \\
5 & 0.1696 & 0.070 & 0.079 \\
6 & 0.1543 & 0.084 & 0.098 \\
7 & 0.0882 & 0.030 & 0.129 \\
8 & 0.0559 & 0.029 & 0.133 \\
9 & 0.0491 & 0.030 & 0.124 \\
10 & 0.0443 & 0.055 & 0.094 \\
11 & 0.0381 & 0.051 & 0.069 \\
12 & 0.0436 & 0.109 & 0.062 \\
13 & 0.0542 & 0.129 & 0.055 \\
\hline
\end{tabular}

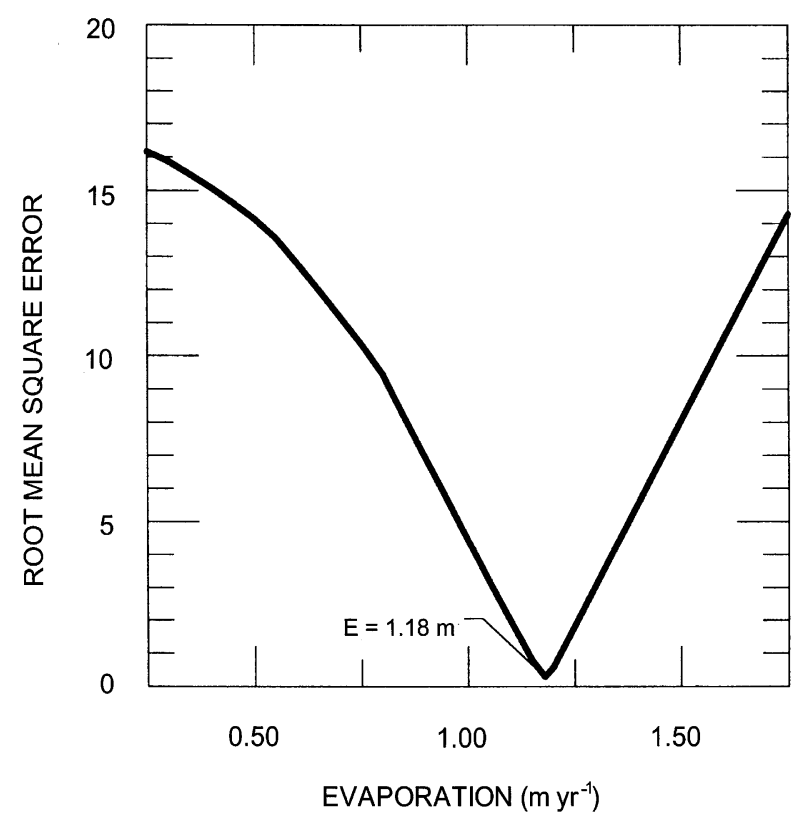

Fig. 20. Optimized Pyramid Lake annual-evaporation rate obtained using calendar-year discharge, precipitation, and measured lake levels for the period 1938-1996. The optimization was based on the minimization of the root-mean-square difference between measured and computed water levels over the period of record.

Instantaneous measurements of Pyramid Lake surface-water temperature between 1985 and 1998 at the Deep Site (Fig. 2) were used to calculate monthly mean values (Table 5). Measurements of air temperature at the Sutcliffe weather station, bordering the west shore of Pyramid Lake (Fig. 2) were also used to calculate monthly mean values (Table 5). Relative humidity data available for October 1987 to October 1989 Hostetler and Benson (1993) were used to calculate

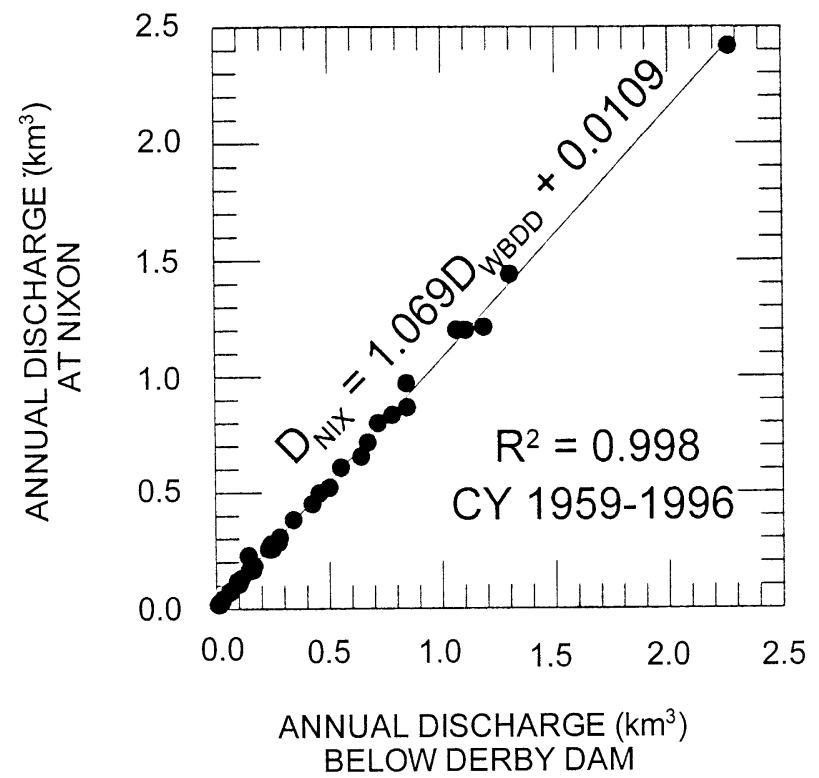

Fig. 21. Correlation between annual (calendar-yr) discharges measured at gages located below the Derby Dam and at Nixon, Nevada (Fig. 2).

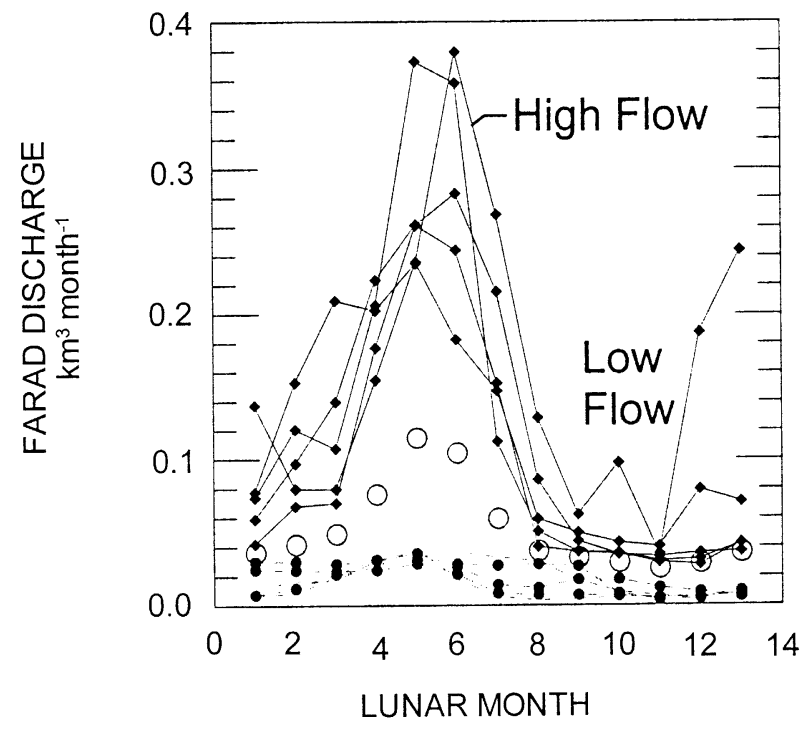

Fig. 22. Plot of Farad monthly discharges during very wet (solid diamonds) and very dry (solid dots) years relative to mean values of Farad discharge (open circles). Note that peak flows occur at the same times in all distributions.

monthly mean values of this parameter (Table 5). Daily values of wind speed from the same source were also examined (Fig. 23) in order to ensure that most daily wind velocities could be associated with an $\alpha_{\text {kin }}$ value of 0.994 . 


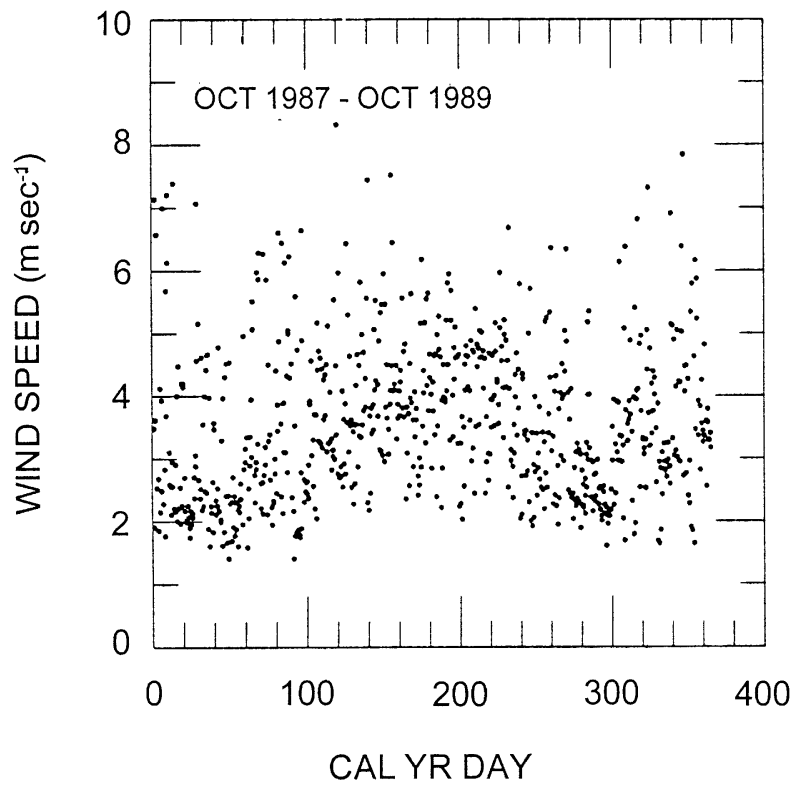

Fig. 23. Daily (24h) wind-speed data for water years 1988 and 1989 (Hostetler and Benson, 1993).

\section{References}

Benson, L.V., 1994. Stable isotopes of oxygen and hydrogen in the Truckee River-Pyramid Lake surface-water system. 1. Data analysis and extraction of paleoclimatic information. Limnology and Oceanography 39, 344-355.

Benson, L.V., 1999. Records of millennial-scale climate change from the Great Basin of the Western United States. In: Clark, P., Webb, R., Keigwin, L. (Eds.), Mechanisms of Global Climate Change at Millennial Time Scales, American Geophysical Union Monograph 112, pp. 203-225.

Benson, L.V., Mifflin, M.D., 1986. Reconnaissance bathymetry of basins occupied by Pleistocene Lake Lahontan, Nevada and California. United States Geological Survey Water-Resource Investigation Report 85-4262, 14pp.

Benson, L.V., White, J.W.C., 1994. Stable isotopes of oxygen and hydrogen in the Truckee River-Pyramid Lake surface-water system 3. Source of water vapor overlying Pyramid Lake. Limnology and Oceanography 39, 1945-1958.

Benson, L.V., Burdett, J.W., Lund, S.P., Kashgarian, M., Mensing, S., 1997. Nearly synchronous climate change in the Northern Hemisphere during the last glacial termination. Nature 388, 263-265.

Benson, L.V., Kashgarian, M., Rye, R., Lund, S., Paillet, F., Smoot, J., Kester, C., Mensing, S., Meko, D., Lindström, S., 2002. Holocene multidecadal and multicentennial droughts affecting Northern California and Nevada. Quaternary Science Reviews 21, 659-682.

Craig, H., Gordon, L.I., 1965. Isotopic oceanography: deuterium and oxygen 18 variations in the ocean and marine atmosphere. In: Schink, D.R., Corless, J.T. (Eds.), Marine Geochemistry. University, Rhode Island, pp. 277-374.

Eicher, U., 1980. Pollen- und Sauerstoffisotopenanalysen an spätglazialen Profilen vom Gerzensee, Faulensee und regenmoos ob boltigen. Mitteilungen der Naturforschenden Gesellschaft in Bern $37,65-80$.
Eicher, U., Siegenthaler, U., 1976. Palynological and oxygen isotope investigations on late-glacial sediment cores from Switzerland. Boreas 5, 109-117.

Fontes, J.C., Melieres, F., Giber, E., Qing, L., Gasse, F., 1993. Stable isotope and radiocarbon balances of two Tibetan lakes (Sumxi CO, Longmu CO) from 13,000 BP. Quaternary Science Reviews 12, 875-887.

Fritz, P., Anderson, T.W., Leqis, C.F.M., 1975. Late quaternary climatic trends and history of Lake Erie from stable isotope studies. Science 190, 267-269.

Gat, J.R., 1970. Environmental isotope balance of Lake Tiberias. In: Isotopes in Hydrology. International Atomic Energy Agency, pp. $109-127$.

Gonfiantini, R., 1965. Isotopic effects in the evaporation of salt water. Atti Society Toscana National Science Pisa 72, 5-22.

Hodell, D.A., Curtis, J.H., Brenner, M., 1995. Possible role of climate in the collapse of classic Maya civilization. Nature 375, 391-394.

Hollett, K.J., Danskin, W.R., McCaffrey, W.F., Walti, C.L., 1991. Geology and Water Resources of Owens Valley, California. US Geological Survey Water-Supply Paper 2370.

Hostetler, S.W., Bartlein, P.J., 1990. Simulation of lake evaporation with application to modeling lake level variations of HarneyMalheur Lake, Oregon. Water Resource Research 26, 2603-2612.

Hostetler, S.W., Benson, L.V., 1993. Meteorological and watertemperature data for Pyramid Lake, Nevada 1987-89. United States Geological Survey Open-File Report 92-159, 15pp.

Hostetler, S., Benson, L.V., 1994. Stable isotopes of oxygen and hydrogen in the Truckee River-Pyramid Lake surface-water system. 2. A predictive model of $\delta^{18} \mathrm{O}$ and $-\delta^{2} \mathrm{H}$ in Pyramid Lake. Limnology Oceanography 39, 356-364.

Johnson, T.C., Halfman, J.D., Showers, W.J., 1991. Paleoclimate of the past 4000 years at Lake Turkana, Kenya, based on the isotopic composition of authigenic calcite. Palaeogeography, Palaeoclimatology, Palaeoecology 85, 189-198.

Lewis, S., 1979. Environmental isotope balance of Lake Kinneret as a tool in evaporation rate estimation. In: Isotopes in Hydrology. International Atomic Energy Agency, Vienna, pp. 33-53.

$\mathrm{Li}, \mathrm{H} ., \mathrm{Ku}, \mathrm{T} .$, 1997. $^{13}-\delta^{18}$ covariance as a paleohydrological indicator for closed-basin lakes. Palaeogeography, Palaeoclimatology, Palaeoecology 133, 69-80.

Lister, G.S., Kelts, K., Zao, C.K., Yu, J., Niessen, F., 1991. Lake Qinghai, China: closed-basin lake levels and the oxygen isotope record for Ostracoda since the latest Pleistocene. Palaeogeography, Palaeoclimatology, Palaeoecology 84, 141-162.

Majoube, M., 1971. Fractionnement en oxygene-18 et en deuterium entre l'eau et sa vapeur. Journal de Chimie Physico 197, 1423-1436.

Merlivat, L., Jouzel, J., 1979. Global climatic interpretation of the deuterium-oxygen 18 relationship for precipitation. Journal Geophysical Research 84, 5029-5033.

Milne, W., 1987. A comparison of reconstructed lake-level records since the mid-1800s of some Great Basin lakes. Unpublished Thesis, Colorado School of Mines.

O’Neil, J.R., Clayton, R.N., Mayeda, T.K., 1969. Oxygen isotope fractionation in divalent metal carbonates. Journal of Chemical Physics 51, 5547-5558.

Oviatt, C.G., Habiger, G.D., Hay, J.E., 1994. Variation in the composition of Lake Bonneville marl: a potential key to lake-level fluctuations and paleoclimate. Journal of Paleolimnology 11, 19-30.

Phillips, F.M., Person, M.A., Muller, A.B., 1986. A numerical model for simulating the isotopic evolution of closed-basin lakes. Journal of Hydrology 85, 73-86.

Phillips, F.M., Campbell, A.R., Kruger, C., Johnson, P., Roberts, R., Keys, E., 1992. A reconstruction of the response of the water balance in western United States lake basins to 
climatic change. Water Resources Research Institute Report 269, $154 \mathrm{pp}$.

Phillips, F.M., Campbell, A.R., Smith, G.I., Bischoff, J.L., 1994. Interstadial climatic cycles: a link between western North America and Greenland? Geology 22, 1115-1118.

Stuiver, M., 1968. Oxygen-18 content of atmospheric precipitation during the last 11,000 years in the Great Lakes region. Science 162, 994-997.

Stuiver, M., 1970. Oxygen and carbon isotope ratios of fresh-water carbonates as climatic indicators. Journal of Geophysical Research $75,5247-5257$.
United States Geological Survey 1916-1996. Water resources data for Nevada. United States Geological Survey Water-data Report Series.

Xia, J., Haskell, B.J., Engstrom, D.R., Ito, E., 1997. Holocene climate reconstructions from tandem trace-element and stable-isotope composition of ostracodes from Coldwater Lake, North Dakota, USA. Journal of Paleolimnology 17, 85-100.

Yurtsever, Y., 1975. Worldwide survey of stable isotopes in precipitation. In: Reports Section of Isotope Hydrology, International Atomic Energy Agency, pp. 567-585. 